\title{
A microarray for assessing transcription from pelagic marine microbial taxa
}

Irina N Shilova ${ }^{1}$, Julie C Robidart ${ }^{1}$, H James Tripp ${ }^{2}$, Kendra Turk-Kubo ${ }^{1}$, Boris Wawrik $^{3}$, Anton F Post ${ }^{4}$, Anne W Thompson ${ }^{5}$, Bess Ward ${ }^{6}$, James T Hollibaugh ${ }^{7}$, Andy Millard ${ }^{8}$, Martin Ostrowski ${ }^{8}$, David J Scanlan ${ }^{8}$, Ryan W Paerl ${ }^{9}$, Rhona Stuart ${ }^{10}$ and Jonathan P Zehr ${ }^{1}$ ${ }^{1}$ Department of Ocean Sciences, University of California Santa Cruz, Santa Cruz, CA, USA; ${ }^{2}$ DOE Joint Genome Institute, Walnut Creek, CA, USA; ${ }^{3}$ Department of Microbiology and Plant Biology, University of Oklahoma, Oklahoma, USA; ${ }^{4}$ Marine Biological Laboratory, Woods Hole, MA, USA; ${ }^{5}$ Advanced Cytometry Group, BD Biosciences, Seattle, WA, USA; ${ }^{6}$ Department of Geosciences, Princeton University, Princeton, NJ, USA; ${ }^{7}$ Department of Marine Sciences, University of Georgia, Athens, GA, USA; ${ }^{8}$ Department of Marine Microbiology, University of Warwick, Coventry, UK; ${ }^{9}$ Marine Biology Research Division, University of California San Diego, San Diego, CA, USA and ${ }^{10}$ Physical and Life Sciences, Lawrence Livermore National Laboratory, Livermore, CA, USA

\begin{abstract}
Metagenomic approaches have revealed unprecedented genetic diversity within microbial communities across vast expanses of the world's oceans. Linking this genetic diversity with key metabolic and cellular activities of microbial assemblages is a fundamental challenge. Here we report on a collaborative effort to design MicroTOOLs (Microbiological Targets for Ocean Observing Laboratories), a high-density oligonucleotide microarray that targets functional genes of diverse taxa in pelagic and coastal marine microbial communities. MicroTOOLs integrates nucleotide sequence information from disparate data types: genomes, PCR-amplicons, metagenomes, and metatranscriptomes. It targets 19400 unique sequences over 145 different genes that are relevant to stress responses and microbial metabolism across the three domains of life and viruses. MicroTOOLs was used in a proof-of-concept experiment that compared the functional responses of microbial communities following Fe and $P$ enrichments of surface water samples from the North Pacific Subtropical Gyre. We detected transcription of $68 \%$ of the gene targets across major taxonomic groups, and the pattern of transcription indicated relief from Fe limitation and transition to N limitation in some taxa. Prochlorococcus (eHLI), Synechococcus (sub-cluster 5.3) and Alphaproteobacteria SAR11 clade (HIMB59) showed the strongest responses to the Fe enrichment. In addition, members of uncharacterized lineages also responded. The MicroTOOLs microarray provides a robust tool for comprehensive characterization of major functional groups of microbes in the open ocean, and the design can be easily amended for specific environments and research questions.

The ISME Journal (2014) 8, 1476-1491; doi:10.1038/ismej.2014.1; published online 30 January 2014

Subject Category: Integrated genomics and post-genomics approaches in microbial ecology

Keywords: marine; microbial; microarray; transcription; molecular
\end{abstract}

\section{Introduction}

Marine microbial communities are complex, composed of diverse groups of Bacteria, Archaea, Eukaryotes and viruses. Molecular techniques frequently used in marine microbial ecology have shown strainspecific differences in genetic capabilities and transcriptional responses among the most abundant representatives of microbial communities (Fuhrman et al., 2006; Giovannoni and Vergin, 2012). Clades of

Correspondence: IN Shilova, Department of Ocean Sciences, University of California Santa Cruz, 1156 High Street, Santa Cruz, CA 95064, USA.

E-mail: iirina@ucsc.edu

Received 29 May 2013; revised 16 December 2013; accepted 31 December 2013; published online 30 January 2014
Prochlorococcus in the North Atlantic have more phosphorus-acquisition strategies than clades in the North Pacific, as an adaptation to chronic phosphate limitation (Coleman and Chisholm, 2010). Coastal clades of Synechococcus have higher number of regulatory systems and the use for metals than open ocean clades, the latter being adapted to relatively constant oligotrophic conditions (Palenik et al., 2006). To link ocean processes to microbial metabolism and to build better models for predicting responses to future ocean states (Azam and Malfatti, 2007), in light of this strain-level heterogeneity, new research tools are needed that assess individual and microbial community responses.

Microarray technology can complement more commonly used molecular techniques, such as PCR and 
next-generation sequencing, to provide cost-effective high-throughput gene and transcript detection from several organisms in a single sample. Microarrays have the advantages of sample replication, standardization and robust interpretations of strain-level variation in functional gene transcriptional patterns and lend themselves to better comparative quantification of specific genes and transcripts, especially in rare organisms.

Phylogenetic and functional microarrays have been developed and used for identification of microorganisms and their activity in diverse environments. The most comprehensive microbial functional microarray to date, the GeoChip 4.0, targets $>10000$ sequences represented by 150 genes mainly from soil microbial communities and reductionoxidation processes (He et al., 2007, 2010; Bai et al., 2013; Zhou et al., 2013). In addition to contaminated soils, acid mine drainage sites and Antarctic soils (Yergeau et al., 2007; Mason et al., 2010; Xie et al., 2011), the GeoChip has been applied to detect microbial DNA and RNA in the marine environment ( $\mathrm{Lu}$ et al., 2012; Wawrik et al., 2012). Aside from the PhyloChip, which targets 16S rRNA genes (Brodie et al., 2006), existing microarrays target a specific genus (Rinta-Kanto et al., 2011), a particular process (Tiquia et al., 2004; Moisander et al., 2006, 2007; Ward et al., 2007; Bulow et al., 2008; Wu et al., 2008; Bouskill et al., 2011; Abell et al., 2012) or ecosystem (Rich et al., 2008; Smith et al., 2010; Rich et al., 2011). A comprehensive microarray that targets functional genes across diverse pelagic marine microbial communities has not yet been reported.

Various strategies have been used to overcome the lack of a priori knowledge of genomic sequences in target communities, which is a major limitation in the design of an environmental microarray. The most common strategy is to search public nucleotide (nt) sequence databases (such as National Center for Biotechnology Information (NCBI)) using key words (Rhee et al., 2004; He et al., 2007; Wu et al., 2008; He et al., 2010; Smith et al., 2010). The resulting data sets, however, typically do not resemble the natural diversity of target genes, a problem that is exacerbated in undersampled environments. A second common strategy is to PCR-amplify a gene of interest and then either spot the products on a glass surface (Wu et al., 2001) or use the derived sequence data in the design of oligonucleotide probes. Although this technique results in a fingerprint for an uncharacterized community and is especially valuable for rare targets (Taroncher-Oldenburg et al., 2003; Moisander et al., 2006; Ward et al., 2007; Bulow et al., 2008), the time-consuming cloning process makes this approach suitable for studying only a limited number of genes. The large nt databases obtained with next-generation sequencing (metagenomics) present an additional opportunity to access a cross-section of the diversity of a marker gene in natural populations.
Here, we report the design and application of a high-density oligonucleotide microarray, referred to as the MicroTOOLs (Microbiological Targets for Ocean Observing Laboratories) microarray, which targets 19400 sequences across 145 genes associated with open ocean and coastal microbial communities. The microarray is based on existing data from genomes, metagenomes, metatranscriptomes and PCR-based assays and targets functional genes responsible for biogeochemical cycling and stress responses characteristic of the oceanic photic zone. As a proof-of-concept experiment, we analyzed microbial community responses to nutrient enrichments of inorganic phosphate (P) or ferric iron (Fe) from the oligotrophic Station (Stn.) ALOHA in the North Pacific Subtropical Gyre (NPSG). The physics, chemistry and biology of this region is well characterized (Karl and Lukas, 1996; White et al., 2007), and its microbial metagenome is well represented in the nt sequence databases (DeLong et al., 2006; Frias-Lopez et al., 2008; Hewson et al., 2010). In the North Pacific, where $\mathrm{N}_{2}$ fixation is a major supply of nitrogen (Karl et al., 1997), phosphorus and iron can be the limiting nutrients for $\mathrm{N}_{2}$ fixation and primary production (Karl et al., 2001; Moore et al., 2006; Grabowski et al., 2008; Karl and Letelier, 2008; Watkins-Brandt et al., 2011). We hypothesized that if microbial taxa were Fe limited, Fe addition would result in decreased transcription of ironstress genes and increased transcription of genes for energy, carbon and nitrogen metabolism. If microbial taxa were $\mathrm{P}$ limited, $\mathrm{P}$ addition would result in decreased transcription of P-stress genes and increased transcription of genes for energy metabolism, DNA replication and cell division. However, we expected to see heterogeneous transcriptional responses from individual taxa owing to differences in their genomic capabilities, nutrient requirements and life strategies (Tolonen et al., 2006; Dupont et al., 2008; Ilikchyan et al., 2009; Stuart et al., 2009; Tetu et al., 2009; Kamennaya and Post, 2011; Thompson et al., 2011).

\section{Materials and methods}

Design of the MicroTOOLs microarray

Target genes for oligonucleotide probe design were selected based on existing knowledge of gene markers that target microorganism interactions with their environment (for example, Lindell and Post, 2001; Webb et al., 2001; Holtzendorff et al., 2002; Chen et al., 2004; Fuller et al., 2005; Dyhrman and Haley, 2006; Zehr et al., 2007; Orchard et al., 2009; Sebastian and Ammerman, 2009; Kamennaya and Post, 2011; Mosier and Francis, 2011; Paerl et al., 2011). Several genes for hypothetical proteins that were differentially expressed in response to specific stimuli in cultured marine microorganisms were also included (Scanlan et al., 1996; Martiny et al., 2009; Shi et al., 2009; Tetu et al., 2009; Thompson 
Table 1 Marker genes targeted in the MicroTOOLs microarray

\begin{tabular}{|c|c|c|c|c|c|c|c|}
\hline Process & Gene & Annotation & Counts & Process & Gene & Annotation & Counts \\
\hline \multirow[t]{19}{*}{$\begin{array}{l}\text { Carbon } \\
\text { metabolism }\end{array}$} & $c d c A$ & $\begin{array}{l}\text { Cadmium containing carbonic } \\
\text { anhydrase }\end{array}$ & 79 & $\begin{array}{l}\text { Nitrogen } \\
\text { metabolism }\end{array}$ & $g \ln B$ & $\mathrm{~N}$ regulatory protein $\mathrm{P}-\mathrm{II}$ & 53 \\
\hline & $\operatorname{chpX}$ & $\mathrm{CO}_{2}$ hydration protein $\mathrm{ChpX}$ & 5 & & hao & Hydroxylamine oxidoreductase & 103 \\
\hline & dca1 & Delta carbonic anhydrase & 31 & & $\operatorname{met} C$ & $\begin{array}{l}\text { Cystathionine beta-lyase family pro- } \\
\text { tein involved in Al resistance }\end{array}$ & 113 \\
\hline & $d x s$ & $\begin{array}{l}\text { 1-deoxy-D-xylulose-5-phosphate } \\
\text { synthase }\end{array}$ & 29 & & $\operatorname{narB}$ & $\begin{array}{l}\text { Assimilatory nitrate reductase in } \\
\text { bacteria }\end{array}$ & 224 \\
\hline & fae & Formaldehyde-activating enzyme & 118 & & nifB & $\begin{array}{l}\text { Nitrogenase cofactor biosynthesis pro- } \\
\text { tein NifB }\end{array}$ & 81 \\
\hline & $f h c D$ & $\begin{array}{l}\text { Formylmethanofuran-tetrahydro- } \\
\text { methanopterin formyltransferase }\end{array}$ & 4 & & nifD & nitrogenase reductase & 95 \\
\hline & gap & $\begin{array}{l}\text { Glyceraldehyde-3-phosphate } \\
\text { dehydrogenase }\end{array}$ & 47 & & nifE & $\begin{array}{l}\text { Nitrogenase MoFe cofactor biosynth- } \\
\text { esis protein NifE }\end{array}$ & 241 \\
\hline & $\operatorname{gid} A$ & Glucose-inhibited division protein A & 152 & & nifH & Nitrogenase iron protein $\mathrm{NifH}$ & 92 \\
\hline & icd & Isocitrate dehydrogenase & 313 & & nifK & $\begin{array}{l}\text { Nitrogenase molybdenum-iron protein } \\
\text { beta chain }\end{array}$ & 265 \\
\hline & mch & $\begin{array}{l}\text { Methenyltetrahydromethanopterin } \\
\text { cyclohydrolase }\end{array}$ & 3 & & $n i f N$ & $\begin{array}{l}\text { Nitrogenase molybdenum-iron cofac- } \\
\text { tor biosynthesis protein NifN }\end{array}$ & 21 \\
\hline & $m t d B$ & $\begin{array}{l}\text { Methylenetetrahydromethanopterin } \\
\text { dehydrogenase }\end{array}$ & 55 & & nifO & Nitrogenase-associated protein NifO & 236 \\
\hline & $\operatorname{mxaF}$ & Methanol dehydrogenase & 71 & & $\operatorname{nifX}$ & $\begin{array}{l}\text { Nitrogenase molybdenum-iron pro- } \\
\text { tein NifX }\end{array}$ & 335 \\
\hline & pmoA & Methane monooxygenase & 140 & & $\operatorname{nir} A$ & ferredoxin-nitrite reductase & 81 \\
\hline & ppc & Phosphoenolpyruvate carboxylase & 104 & & $\operatorname{nirS}$ & Dissimilatory nitrite reductase & 159 \\
\hline & $\operatorname{prs} A$ & Ribose-phosphate pyrophosphokinase & 275 & & $\operatorname{nir} X$ & Homeobox domain, in the nirA operon & 73 \\
\hline & pyk & Pyruvate kinase & 163 & & $N R$ & Assimilatory nitrate reductase & 227 \\
\hline & $r b c L$ & RuBisCO & 1 & & $n r t P$ & Nitrate transporter & 98 \\
\hline & $\operatorname{sbt} A$ & $\begin{array}{l}\text { Sodium-dependent bicarbonate } \\
\text { transporter }\end{array}$ & 75 & & $n t c A$ & N limitation transcriptional regulator & 195 \\
\hline & $z w f$ & Glucose-6-phosphate dehydrogenase & 41 & & $\operatorname{slc} 17 A$ & Amino-acid transporter & 540 \\
\hline \multirow[t]{10}{*}{$\begin{array}{l}\text { Cell cycle and } \\
\text { replication }\end{array}$} & $\begin{array}{l}\text { CwatDRAFT } \\
4045\end{array}$ & Transposase CwatDRAFT_4045 & 41 & & Tery_2117 & Hypothetical protein, expressed as nif & 173 \\
\hline & $\operatorname{dnaA}$ & Replication-initiation protein & 20 & & Tery_2900 & Hypothetical protein, expressed as nif & 476 \\
\hline & $d n a E$ & DNA polymerase III, alpha subunit & 110 & & Tery_4333 & $\begin{array}{l}\text { LysR family transcriptional regulator, } \\
\text { expressed as nif }\end{array}$ & 11 \\
\hline & elaC & Ribonuclease Z & 97 & & ure & Urea transporter & 229 \\
\hline & fts $Z$ & Cell division protein FtsZ & 6 & & ureA & Urease alpha subunit & 53 \\
\hline & kaiC & Circadian clock protein KaiC & 609 & & ureB & Urease beta subunit & 54 \\
\hline & pol & DNA polymerase & 226 & & ureC & Urease & 11 \\
\hline & rec $A$ & Recombinase A & 222 & & ureD & Urease accessory protein UreD & 755 \\
\hline & rpoD & RNA polymerase sigma factor & 42 & & ureE & Urease accessory protein UreE & 282 \\
\hline & $\operatorname{sig} A$ & RNA polymerase sigma factors & 401 & & ureF & Urease accessory protein UreF & 599 \\
\hline \multirow{5}{*}{$\begin{array}{l}\text { DMSP } \\
\text { metabolism }\end{array}$} & $d d d D$ & DMSP CoA transferase & 80 & & ureG & Urease accessory protein UreG & 482 \\
\hline & $d d d L$ & DMSP lyase & 238 & & ureH & $\begin{array}{l}\text { Urease accessory protein UreH-like } \\
\text { protein }\end{array}$ & 854 \\
\hline & $d d d P$ & DMSP lyase & 30 & & ureX & urease subunit & 491 \\
\hline & $d d d Q$ & DMSP lyase & 4 & & urtA & $\begin{array}{l}\text { Urea ABC transporter, substrate-bind- } \\
\text { ing protein }\end{array}$ & 33 \\
\hline & $d m d A$ & $\begin{array}{l}\text { Dimethyl sulfoniopropionate } \\
\text { demethylase }\end{array}$ & 35 & $\begin{array}{l}\text { Other } \\
\text { metabolisms }\end{array}$ & bop & Proteorhodopsin & 552 \\
\hline \multirow{11}{*}{$\begin{array}{l}\text { Energy } \\
\text { metabolism }\end{array}$} & $\operatorname{cox} A$ & Cytochrome $C$ oxidase subunit I & 16 & & $\operatorname{chr} A$ & Chromate transporter & 276 \\
\hline & $\operatorname{cox} B$ & Cytochrome $c$ oxidase subunit II & 4 & & $\operatorname{cobN}$ & Cobaltochelatase CobN & 36 \\
\hline & срсB & Phycocyanin, beta subunit & 5 & & mopA & $\begin{array}{l}\text { Heme-binding region from putitive } \\
\text { Mn-oxidase }\end{array}$ & 10 \\
\hline & hupS & $\begin{array}{l}\text { Ni-Fe hydrogenase, small subunit } \\
\text { HupS }\end{array}$ & 51 & Other stresses & $m f s$ & $\begin{array}{l}\text { Multidrug efflux transporter, proline/ } \\
\text { betaine transporter }\end{array}$ & 374 \\
\hline & $n d h I$ & NADH dehydrogenase subunit I & 11 & & NiSOD & $\begin{array}{l}\text { Putative nickel-containing superoxide } \\
\text { dismutase precursor }\end{array}$ & 468 \\
\hline & petB & Cytochrome b6f & 154 & & NUDIX & nudix hydrolase & 22 \\
\hline & $\operatorname{psaA}$ & $\begin{array}{l}\text { Photosystem I P700 chlorophyll a } \\
\text { apoprotein A1 }\end{array}$ & 149 & & phrB & DNA photolyase & 172 \\
\hline & $p s a B$ & $\begin{array}{l}\text { Photosystem I P700 chlorophyll } a \\
\text { apoprotein A10 }\end{array}$ & 30 & & pip & Proline iminopeptidase & 177 \\
\hline & $p s b A$ & Photosystem II PsbA protein (D1) & 5 & & pmm1148 & EF-1 guanine nucleotide exchange & 279 \\
\hline & psbA1 & Photosystem II PsbA protein (D1) & 4 & & pmm1462 & $\begin{array}{l}\text { Conserved hypothetical protein } \\
\text { PMM1462 }\end{array}$ & 1 \\
\hline & psbA2 & Photosystem II PsbA protein (D1) & 269 & & ptox & Plastoquinol terminal oxidase & 9 \\
\hline
\end{tabular}


Table 1 (Continued)

\begin{tabular}{|c|c|c|c|c|c|c|c|}
\hline Process & Gene & Annotation & Counts & Process & Gene & Annotation & Counts \\
\hline & $p s b B$ & Photosystem II PsbB protein (CP47) & 262 & & $\operatorname{sigII}$ & $\begin{array}{l}\text { Type II alternative sigma-70 family } \\
\text { RNA polymerase sigma factor }\end{array}$ & 5 \\
\hline \multirow{20}{*}{$\begin{array}{l}\text { Iron } \\
\text { metabolism }\end{array}$} & $a b c 1$ & ABC1 superfamily protein & 55 & & $\operatorname{sod} C$ & $\mathrm{Cu}-\mathrm{Zn}$ superoxide dismutase & 1 \\
\hline & $\operatorname{cir} A$ & $\begin{array}{l}\text { Ferric iron-catecholate outer mem- } \\
\text { brane transporter }\end{array}$ & 6 & $\begin{array}{l}\text { Phosphorus } \\
\text { metabolism }\end{array}$ & acr3 & Arsenite transport (efflux) & 25 \\
\hline & $d p s A$ & Ferritin-like diiron-binding domain & 15 & & $\operatorname{ars} C$ & Arsenate reductase & 4 \\
\hline & feoA & Ferrous iron transport protein A & 9 & & $\operatorname{glp} Q$ & $\begin{array}{l}\text { Glycerophosphoryl diester } \\
\text { phosphodiesterase }\end{array}$ & 40 \\
\hline & $f e p B$ & $\begin{array}{l}\text { ABC-type } \mathrm{Fe} 3+- \text { hydroxamate } \\
\text { transport system }\end{array}$ & 3 & & $\operatorname{phn} A$ & Phosphonoacetate hydrolase & 252 \\
\hline & fepC & $\begin{array}{l}\text { ABC-type cobalamin } / \mathrm{Fe} 3+- \\
\text { siderophores transport systems }\end{array}$ & 209 & & phnD & Phosphonate transporter & 1 \\
\hline & fepD & $\mathrm{Fe} 3+$ siderophore transport system & 1035 & & phnJ & Phosphonate lyase & 173 \\
\hline & fld $A($ isiB) & Flavodoxin eukaryotic & 3 & & phoA & Alkaline phosphatase, $\mathrm{Zn}^{2+}$ binding & 600 \\
\hline & fld $B$ & Flavodoxin & 217 & & phoD & Alkaline phosphatase & 2 \\
\hline & fur & Ferric transcriptional regulator & 2 & & phoH & P stress-inducible protein & 2 \\
\hline & idiA & Iron (III) transporter & 365 & & phoU & $\begin{array}{l}\text { Transcriptional regulator, phosphate } \\
\text { transport system protein }\end{array}$ & 143 \\
\hline & isiA & $\begin{array}{l}\text { Iron stress-induced chlorophyll-bind- } \\
\text { ing protein }\end{array}$ & 12 & & phoX & Alkaline phosphatase, $\mathrm{Ca}^{2+}$ binding & 2 \\
\hline & $i s i B$ & Flavodoxin & 213 & & polyP1 & Poly-phosphate accumulation & 4 \\
\hline & isiP & Iron stress-induced protein & 302 & & psiP & Highly expressed under low P & 1 \\
\hline & pep_m20 & $\begin{array}{l}\text { Possible Peptidase family M20/M25/ } \\
\text { M56 }\end{array}$ & 11 & & pstS & Phosphate transporter & 1 \\
\hline & petF & Ferredoxin & 16 & & $\operatorname{ptr} A$ & Possible P transcriptional regulator & 3 \\
\hline & piuC & $\begin{array}{l}\text { Uncharacterized iron-regulated } \\
\text { protein }\end{array}$ & 9 & & $s q d B$ & Sulfolipid biosynthesis protein & 3 \\
\hline & pmm1359 & $\begin{array}{l}\text { Predicted membrane protein, iron- } \\
\text { stress responsive }\end{array}$ & 48 & $\begin{array}{l}\text { Silica } \\
\text { transport }\end{array}$ & sit & Silicon transporter & 5 \\
\hline & $p v s B$ & Vibrioferrin biosynthesis protein PvsB & 257 & & sit1 & Silicon transporter & 4 \\
\hline & sam & SAM-methyltransferase & 98 & & sit2 & Silicon transporter & 167 \\
\hline \multirow{7}{*}{$\begin{array}{l}\text { Nitrogen } \\
\text { metabolism }\end{array}$} & aapJ & Polar amino-acid ABC transporter & 66 & & sit3 & Silicon transporter & 4 \\
\hline & amoA & Ammonia oxidation & 5 & Viral genes & dnaPol & Viral DNA polymerase & 6 \\
\hline & amt & Ammonium transporter & 5 & & g20 & Viral capsid assembly protein g20 & 7 \\
\hline & $\arg$ & $\mathrm{N}$-acetyl transferase & 6 & & gp23 & Viral major capsid proteins & 1 \\
\hline & $\operatorname{car} A$ & Carbamoyl-phosphate synthase & 5 & & mсp & Viral major capsid proteins & 1 \\
\hline & $\operatorname{cyn} A$ & Cyanate transporter & 5 & & $R d R p$ & RNA-dependent RNA pol & 292 \\
\hline & $\operatorname{gln} A$ & Glutamine synthetase & 1 & & & & \\
\hline
\end{tabular}

Abbreviations: DMSP, dimethylsulfoniopropionate; MicroTOOLs, Microbiological Targets for Ocean Observing Laboratories. Counts refer to gene ortholog counts on the array.

et al., 2011). A total of 145 genes provided molecular markers for metabolic and cellular processes (Table 1).

To obtain gene probes that adequately represent environmental nt diversity, we searched all marine metagenomic and metatranscriptomic databases along with sequences from clone libraries for known genes. For metagenomic and metatranscriptomic searches, a seed amino-acid sequence data set was built for selected taxa (Supplementary Material) for each targeted gene. This seed data set was used for a TBLASTN query against 'All Sanger reads' and 'All 454 reads' in the Community Cyberinfrastructure for Advanced Microbial Ecology Research and Analysis (CAMERA, http://camera.calit2.net/, Sun et al., 2011) with loose criteria: an E value cutoff of 1.0E03 and up to 1000 hits per query. All TBLASTN hits with lengths $>150 \mathrm{nt}$ were used as queries in reciprocal BLASTX in CAMERA to confirm gene annotation. For this analysis, an E value cutoff of
$1 \mathrm{E}-10$ and $60 \%$ identity over a minimum 40 amino acid alignment were used. Subsequent BLASTN searches in CAMERA were used to retrieve corresponding taxonomic information. Sequences with $>85 \%$ identity over $100 \mathrm{nt}$ alignment length to targeted marine microorganisms were selected. Taxonomic affiliation means that the target sequence had the highest similarity to a specific organism by BLASTN search against the 'nr' database. Thus, the accuracy of affiliation to an organism depended on gene conservation and their representation in sequence databases. NimbleGen technology allows $5 \%$ nt mismatch in the whole probe region, thus sequences within a range of $95-100 \%$ nt identity to the target gene were detected. We use the phrase 'organism-like genotype' to refer to target gene affiliation if nt identity of the target gene to this organism was $<95 \%$. After reciprocal BLAST, sequences originating from metagenomic libraries that contained nontranscribed regions were trimmed at $5^{\prime}$ - and $3^{\prime}$-ends 
of the open reading frame region. Custom Java applications and R scripts were developed to filter all BLAST results and to trim the ends of sequences and are available upon request. Additionally, target sequences were added that derived from the clone libraries of genes (Supplementary Material) and from genomes of marine microorganisms contained in NCBI Genbank. Combined sequences were clustered using CD-HIT-EST (Li and Godzik, 2006; Huang et al., 2010) at 95\% nt similarity. The longest representative sequence from each cluster was selected as the target sequence for oligonucleotide probe design. Probe design was performed at Roche NimbleGen (Madison, WI, USA), and six probes of 60-nt length were designed for each target. Random oligonucleotide probes were included in addition to standard control and alignment NimbleGen probes. All oligonucleotide probes were tested in silico for possible cross-hybridization (Supplementary Material). Before the MicroTOOLs microarray design, we tested the specificity of oligonucleotide microarray technology in detecting transcripts from a mixed community and from environmental samples. The results showed cross-hybridization for highly conserved genes (such as the photosystem II psbA gene across cyanobacteria) when nt sequences were $<5 \%$ dissimilar (Supplementary Material, Supplementary Figure S1). The final design of the MicroTOOLs microarray comprised of ca. 116000 experimental and 19000 control probes with one replication synthesized on a 12-plex $12 \times 135 \mathrm{~K}$ NimbleGen array. The platform is available at NCBI Gene Expression Omnibus (www.ncbi.nlm.nih.gov/geo/) under accession number GPL16706.

\section{Nutrient-enrichment incubation}

An incubation experiment was performed at Stn. ALOHA $\left(22^{\circ} 45^{\prime} \mathrm{N} 158^{\circ} \mathrm{W}\right)$ in the NPSG during KM1016 cruise (R/V Kilo-Moana). Surface water was collected on 22 August 2010 from $10 \mathrm{~m}$ depth using Niskin bottles in a rosette mounted to a conductivitytemperature-depth instrument (cast S2c9), filtered through $10.0-\mu \mathrm{m}$ pore-size mesh, and distributed into 12 4-1 clear polycarbonate bottles. The bottles and tubing were cleaned with $10 \% \mathrm{HCl}$, but vigorous trace-metal cleaning precautions were not taken during experimental setup. Each treatment was done in triplicate: (1) control (no enrichment), (2) enrichment with $1.0 \mu \mathrm{M} \mathrm{K}_{2} \mathrm{PO}_{4}$, and (3) enrichment with $2.0 \mathrm{~nm} \mathrm{FeCl}_{3}$. The bottles were incubated in a deck incubator continuously flushed with surface seawater to maintain the proper temperature. Neutral density screening was used to attenuate sunlight to ca. $35 \%$ of surface sunlight. Four-liter samples were taken from the original seawater sample before nutrient additions (three replicates total) and from all treatments after $48 \mathrm{~h}$ of incubation in the morning. From each bottle, 3.9l were then filtered onto Sterivex cartridges $(0.22 \mu \mathrm{m}$, Millipore, Billerica, MA, USA) using gentle Masterflex (Cole Parmer,
Vernon Hills, IL, USA) peristaltic pumping ensuring that filtration time did not exceed 25 min. Sterivex cartridges were immediately flash frozen in liquid nitrogen and stored at $-80{ }^{\circ} \mathrm{C}$ until processing. The remaining $0.1 \mathrm{l}$ from each bottle was used in Fast Repetition Rate Fluorometer (FRRF) analysis.

RNA extraction and processing for hybridization to the microarray

RNA was extracted using the Ambion RiboPure kit (Life Technologies, Grand Island, NY, USA) with modifications that included mechanical lysis using glass beads (Supplementary Material). Extracted RNA was treated with DNase to remove genomic DNA. RNA quantity and quality were determined with a NanoDrop 1000 (Thermo Scientific, Waltham, MA, USA) and a 2100 Bioanalyzer (Agilent Technologies, Santa Clara, CA, USA) using the RNA 6000 Nano kit (Agilent Technologies). Only samples with RNA Integrity Number $>7.0$ and ratios of A260/A230 and A260/A280 $\geqslant 1.8$ were processed further. RNA yield from the incubations of the surface community at Stn. ALOHA ranged from 280 to $1130 \mathrm{ngl}^{-1}$, an amount insufficient for the NimbleGen microarray. cDNA was synthesized from 400 ng RNA from each sample, which was then amplified using the TransPlex Whole Transcriptome Amplification kit (WTA-1, Sigma-Aldrich, St Louis, MO, USA) and antibody-inactivated hot-start Taq DNA Polymerase (Sigma-Aldrich). The amplified cDNA was purified with the GenElute PCR cleanup kit (Sigma-Aldrich), and the quality and quantity of double-stranded (ds) cDNA was determined with NanoDrop 1000 and a 2100 Bioanalyzer using the Agilent DNA 7500 kit (Agilent Technologies). Four hundred nanograms of total RNA yielded on average $12 \mu \mathrm{g}$ of ds-cDNA. The amplification efficiency was determined with a TaqMan quantitative PCR (qPCR) assay targeting a spike-in transcript ERCC-00116 (Invitrogen, Life Technologies). One microliter of 1:100 dilution (corresponding to 4.7 attomoles of ERCC-0016) of the ERCC (External RNA Control Consortium, Lemire et al., 2011) RNA spike-in mix 1 (Ambion) was added to RNA samples before amplification. Amplification of one replicate for $\mathrm{Fe}$ treatment was seven times less than the average amplification (150-fold), and the sample was excluded from microarray hybridization. The labeling and hybridization of cDNA samples $(1.0 \mu \mathrm{g}$ of ds-cDNA) to the microarray was done at the Sandler Center Functional Genomics Core Facility (University of California, San Francisco, CA, USA) according to the protocol in NimbleGen Arrays User's Guide: 'Gene Expression Arrays, version 6.0'.

DNA extraction and estimation of cell abundances for diazotrophs and Synechococcus spp.

DNA was extracted from the organic phase of the nucleic acid extract after RNA separation using the RiboPure kit (Ambion) according to the 
manufacturer's instructions (Supplementary Material). DNA yield ranged from 9.2 to $26.6 \mu \mathrm{gl}^{-1}$. Diazotroph abundances were determined with Taqman qPCR assays targeting nifH as described in Moisander et al. (2010). Synechococcus spp. cell abundances were estimated using the qPCR assay targeting narB (group G) as described in Paerl et al. (2012). The Tukey's test was used to compare the qPCR data.

\section{Microarray data analysis}

All data analyses were performed with $\mathrm{R}$ (www. R-project.org) and the Bioconductor project (Gentleman et al., 2004), specifically using the Linear Models for Microarray (LIMMA; Smyth, 2005), affy (Gautier et al., 2004) and samr (Tusher et al., 2001) packages; plots were made using gplots package. Transcription values were obtained using the robust multi-array average algorithm (Irizarry et al., 2003) and using Li-Wong across-chip normalization (Li and Wong, 2001) (Supplementary Figure S2). The signal-to-noise ratio (SNR) of each chip was calculated as: $\mathrm{SNR}=\left(\mathrm{S}_{\mathrm{i}}-\mathrm{BG}\right) / \mathrm{BG}$; where $\mathrm{S}_{\mathrm{i}}$ is the hybridization signal for the gene and BG is the chip background signal determined as average of the lowest $5 \%$ of all signals. Transcription was considered detected if SNR of a transcript was $\geqslant 5$. The detection range was estimated based on the ERCC hybridization data (Supplementary Figure S3). The detection limit as percentage of total mRNA was calculated for 1000-nt long mRNA and considering that rRNA constitutes $95 \%$ of total RNA. The relative cell sensitivity limit was estimated based on the assumption of 1380 mRNA per cell (Neidhardt and Umbarger, 1996). For each group (Eukaryota, Bacteria non-picocyanobacteria, Prochlorococcus, Synechococcus, Viruses, Archaea), gene transcription was scaled to the median of the group in each sample. To identify differentially transcribed genes, the nonparametric method, Significance Analysis of Microarray (Tusher et al., 2001) was used with the following parameter settings: delta $=0.3,100$ iterations, false discovery rate $(\mathrm{FDR})=0.05$ (Supplementary Figure S4). In addition, LIMMA (Smyth, 2005) was used with the following parameters: fold change in $\log _{2}$ scale $=1$; FDR $=0.05 ; P<0.1$ (Benjamini-Hochberg adjusted, Benjamini and Hochberg, 1995). The separation of samples by treatment was supported by a Wilcoxon's test (Bauer, 1972) performed with at least a 100 random resamplings of 1000 gene probes (Supplementary Figure S4). Transcription data was centered and scaled across genes, and a distance matrix was calculated by Pearson's correlation coefficient. The distance matrix was then used in hierarchical clustering by a complete agglomeration method. Raw and normalized microarray data were prepared in accordance to the MIAME standards (Brazma et al., 2001) and submitted to NCBI GEO under accession number GSE44448.
FRRF measurements

Chlorophyll $a$ variable fluorescence (Fv) and maximal fluorescence (Fm) were measured using FRRF as described in Kolber et al. (1998). FRRF measurements were taken for each sample in the beginning and after $48 \mathrm{~h}$ of incubation in six replications and using blue light $(470 \mathrm{~nm}$ ) for excitation. The Tukey's test was used to compare the FRRF data.

\section{Results and discussion}

Microarray design

The MicroTOOLs microarray targets marker genes for three domains of life in marine microbial communities along with known viruses. Using our approach, a total of 19400 target sequences representing 145 genes (Table 1) were obtained from genomes $(\sim 8 \%)$ and from metagenomes/metatranscriptomes $(\sim 92 \%)$. The design was biased toward the picocyanobacteria Prochlorococcus and Synechococcus spp. and the Alphaproteobacteria clade SAR11 sequences (Figure 1, Supplementary Table S1) owing to their high abundances in surface oceanic waters, resulting in high abundances of their nt sequences in metagenomes and metatranscriptomes (for example, DeLong et al., 2006; Hewson et al., 2010) and the fact that gene function and diversity of these microorganisms have been relatively well studied (Scanlan and West, 2002; Scanlan et al., 2009; Sun et al., 2011; Brown et al., 2012). Genes from less abundant prokaryotic microorganisms, such as from marine $\mathrm{N}_{2}$-fixing cyanobacteria, were also included. Marine eukaryotic phytoplankton were primarily represented by the genes encoding the large subunit of RuBisCO ( $r b c L)$ and nitrate reductase (NR) (Figure 1). Additional eukaryotic genes were selected based on available genomes and/or expressed sequence tags for diatoms (Armbrust et al., 2004; Bowler et al., 2008). Genes for marine DNA and RNA viruses included genes for DNA polymerase, major capsid protein and RNA-dependent RNA polymerase. Probes for Archaea targeted genes encoding ammonia monooxygenase, RuBisCO and urease (Supplementary Table S1).

As a proof of concept, the transcriptional responses of the surface microbial community at Stn. ALOHA to phosphate (P) or iron (Fe) amendments were analyzed using the MicroTOOLs microarray. During the time of sampling, surface waters at Stn. ALOHA had $54-79 \mathrm{nmoll}^{-1}$ of P, 4-33 $\mathrm{nmoll}^{-1}$ of nitrate plus nitrite, $0.79-1.07 \mu \mathrm{moll}^{-1}$ of silicon and $67-78 \mathrm{ngl}^{-1}$ of chlorophyll $a$ (data from $5-10 \mathrm{~m}$ depths). $\mathrm{Fe}$ concentrations were not measured during the time of study, but average near-surface Fe concentration at Stn. ALOHA is $0.44 \mathrm{nmoll}^{-1}$ (Boyle et al., 2005). The long-term mean P concentrations at Stn. ALOHA are $58 \pm 3 \mathrm{nmoll}^{-1}$ (Björkman et al., 2012), and thus, out of $\mathrm{P}$ and $\mathrm{Fe}, \mathrm{Fe}$ was believed to be the limiting nutrient at the time of incubation, at least for the diazotrophic community. 
Microbial community transcription at Stn. ALOHA detected with the MicroTOOLs microarray

Hybridization signals above background were detected for a total of 15507 genes (68\% of the microarray set), with an average detection of $40 \%$ of target orthologs for each gene (Supplementary Table S3). The range of detection for the microarray was from 700 to $11 \mathrm{E}+06$ transcript copies based on the spike-in ERCC data (Supplementary Figure S3). Calculated for a 1000-nt long mRNA, the 700 transcript copies (absolute sensitivity) corresponded to $1.8 \mathrm{E}-06 \%$ of the total community mRNA and to $0.0025 \%$ as the lowest relative abundance of cells within the community that can be detected. Average transcription from pelagophytes (Aureococcus) and prymnesiophytes (Chrysochromulina, Phaeocystis, Helicosphaera) was up to sixfold higher than the median transcription in all eukaryotes across samples (Figure 2a, Supplementary Table S2). Average transcription among prokaryotes (Prochlorococcus, Synechococcus, Proteobacteria,) was distributed around the median transcription of the corresponding transcriptome in all samples (Figure 2a, insert). The exceptions were genes related to an uncultured Prochlorococcus species represented by a fosmid clone HOTOM, which had 16-fold higher transcription than the median (Figure 2a). The most highly transcribed genes across all treatments were psaA (photosystem I), psbA (photosystem II), amt (ammonium transport), urtA (urea transporter) and $r b c L$ (Figure 2b). Among relatively low abundance taxa, diazotrophic cyanobacteria, Trichodesmium erythraeum IMS101, Candidatus Atelocyanobacterium thalassa ( $\mathrm{Ca}$. A. thalassa or unicellular cyanobacterial group A, UCYN-A) and an uncultured heterocystous cyanobacterium (NCBI 112280460, Moisander et al., 2007) had high nifH (Fe-nitrogenase reductase) transcription (Supplementary Table S2). The maximum nifH transcription in these cyanobacteria occurs during the early morning hours (Church et al., 2005), when samples from incubations were collected. Another $\mathrm{N}_{2}$-fixing cyanobacterium Crocosphaera watsonii (Crocosphaera) had high transcription of pstS (high-affinity phosphate binding) and ftsZ (cell division) (Supplementary Table S2). Ca. A. thalassa and Crocosphaera cell abundances (Table 2) in the incubations ranged from $0.0002 \%$ to $0.04 \%$ of the

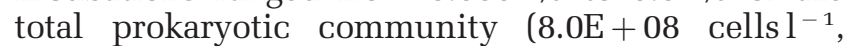
Bjorkmann et al., 2012), overlapping the estimated relative cell detection limit for the microarray $(0.0025 \%)$. In addition, gene transcripts were detected for members of the Phycodnavirus family, which infects a number of eukaryotic phytoplankton, including Micromonas (Mayer and Taylor, 1979) and Aureococcus (Milligan and Cosper, 1994) and also for cyanophages from the Myoviridae family (DNA polymerase and viral capsid genes).

Overall, the genes with detected transcription reflected the composition and activity of the microbial community at Stn. ALOHA as previously described (DeLong et al., 2006; Frias-Lopez et al., 2008; Church et al., 2009; Hewson et al., 2010). Moreover, the high activity of the pelagophytes and prymnesiophytes was consistent with the detection of a eukaryotic phytoplankton bloom at that time (Björkman et al., 2012).

Transcription by members of unknown lineages A wide diversity of genotypes of Prochlorococcus, Synechococcus and Alphaproteobacteria were detected at the study site. Prochlorococcus probes that yielded detectable signals had a wide range of nt similarity to sequenced genomes (Figures 3a and d), indicating a broad representation of the known natural genetic diversity in Prochlorococcus, as well as transcriptional activity in genotypes with no currently sequenced genome. Gene probes with detectable transcription had a median of $91 \%$ nt identity to Prochlorococcus genome sequences, such as strain CCMP1986 (Figure 3a).

Detected Synechococcus-like transcripts had a median of $88.5 \%$ similarity at the nt level to their orthologs in known genomes (Figures $3 \mathrm{~b}$ and $\mathrm{d}$ ). Especially high transcriptional activity (normalized transcription $>2$ ) was detected for genes similar to Synechococcus sp. RCC307, a strain from Synechococcus sub-cluster 5.3A. The low percentage of similarity to known genomes indicates the existence of an uncharacterized lineage, potentially within the sub-cluster 5.3, at Stn. ALOHA. The presence of this clade has recently been reported in the open ocean and in the Mediterranean Sea, with higher abundances in warm, low-nutrient waters (MellaFlores et al., 2011; Post et al., 2011; Ahlgren and Rocap, 2012; Huang et al., 2012).

With a median of $80.0 \%$ similarity, probe sequences targeting Alphaproteobacteria also displayed a degree of degeneracy relative to known genome sequences (Figure 3c), suggesting that new, active strains remain uncharacterized. This is consistent with another recent study, where a new group of the SAR11 clade was proposed based on $16 S$ rRNA gene phylogeny (Allen et al., 2012). Such uncharacterized genotypes with detectable transcription are candidates for further targeted genomic studies.

\section{Response to nutrient amendments}

Maximum chlorophyll a fluorescence (Fm) was not significantly different between each of the amendments and the control and between $\mathrm{P}$ and Fe amendments $(P>0.2$, Table 2). The lower ratio of variable to maximum fluorescence $(\mathrm{Fv} / \mathrm{Fm})$ in the $\mathrm{Fe}$ treatment $(P<0.05)$ may be a result of either a shift in phytoplankton community composition or lower photosynthetic efficiency in Fe-enriched samples due to nutrient limitation (Vogel et al., 2003; Sylvan et al., 2007, 2011). 
a
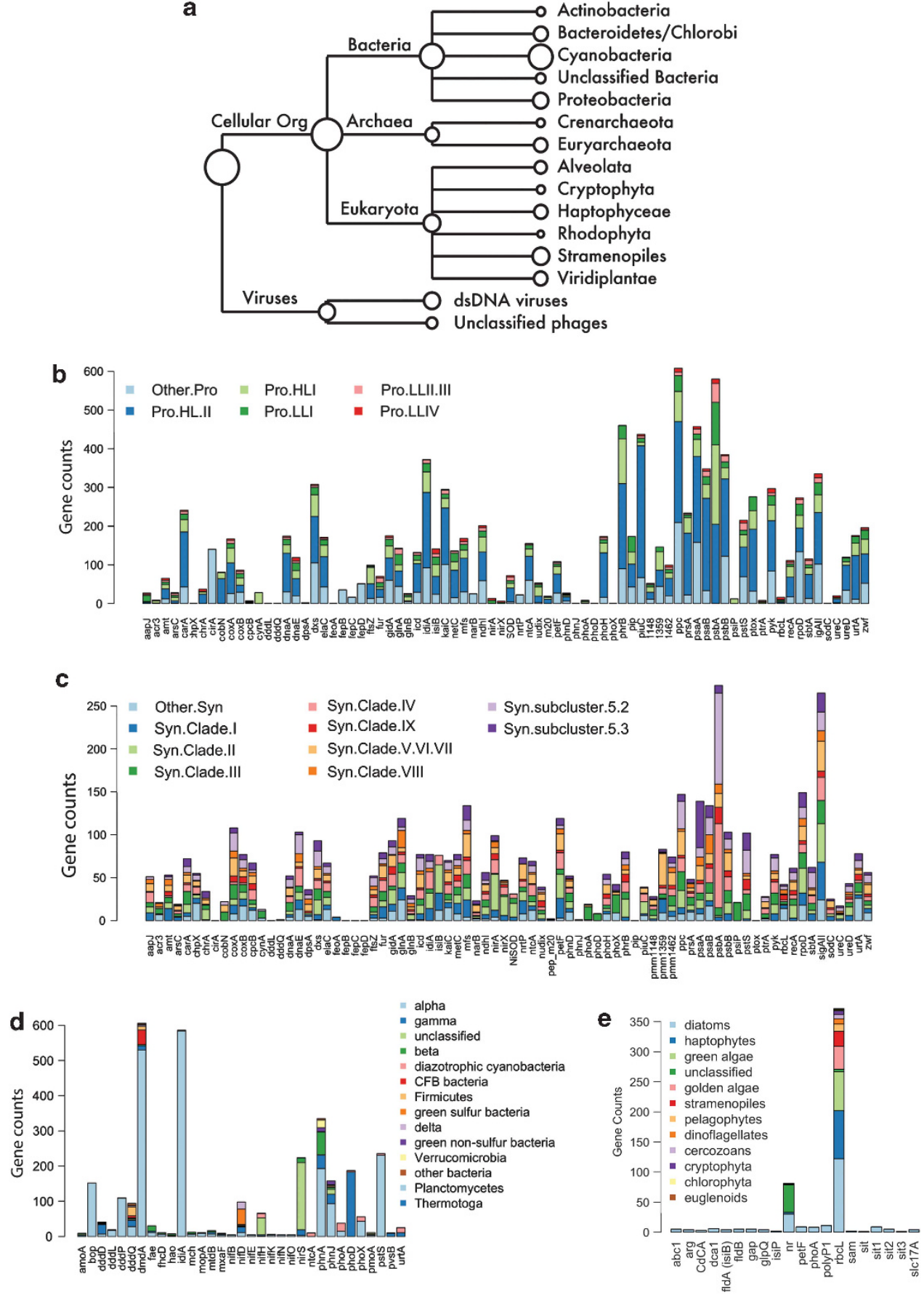

Figure 1 Microorganisms and viruses with genes targeted in the MicroTOOLs microarray. (a) Phylogenetic tree of all targeted genes with the number of genes reflected in the size of the circles. (b-e) Distribution of target genes in (b) Prochlorococcus spp. by clade, (c) Synechococcus spp. by clade, (d) bacteria other than Prochlorococcus and Synechococcus by phylogroups and (e) Eukaryota by phylogroup. The details for gene distribution are in Supplementary Table S1.

Cyanobacterial abundances increased in response to $\mathrm{Fe}$ amendments. Diazotrophic cyanobacteria Crocosphaera and Ca. A. thalassa and the nondiazotrophic cyanobacteria Synechococcus were 8, 19 and 23 times, respectively, more abundant in Fe amendments versus the control after incubation, as measured with qPCR (Table 2). Ca. A. thalassa and Synechococcus spp. were 8 and 11 times, respectively, more abundant in Fe-amended versus $\mathrm{P}$-amended samples. This high increase in cell abundances in response to $\mathrm{Fe}$ and low response to $\mathrm{P}$ is consistent with previously reported variability in responses of diazotrophs to $\mathrm{P}$ and $\mathrm{Fe}$ availability in the NPSG (Zehr et al., 2007; Grabowski et al., 2008; Watkins-Brandt et al., 2011). 

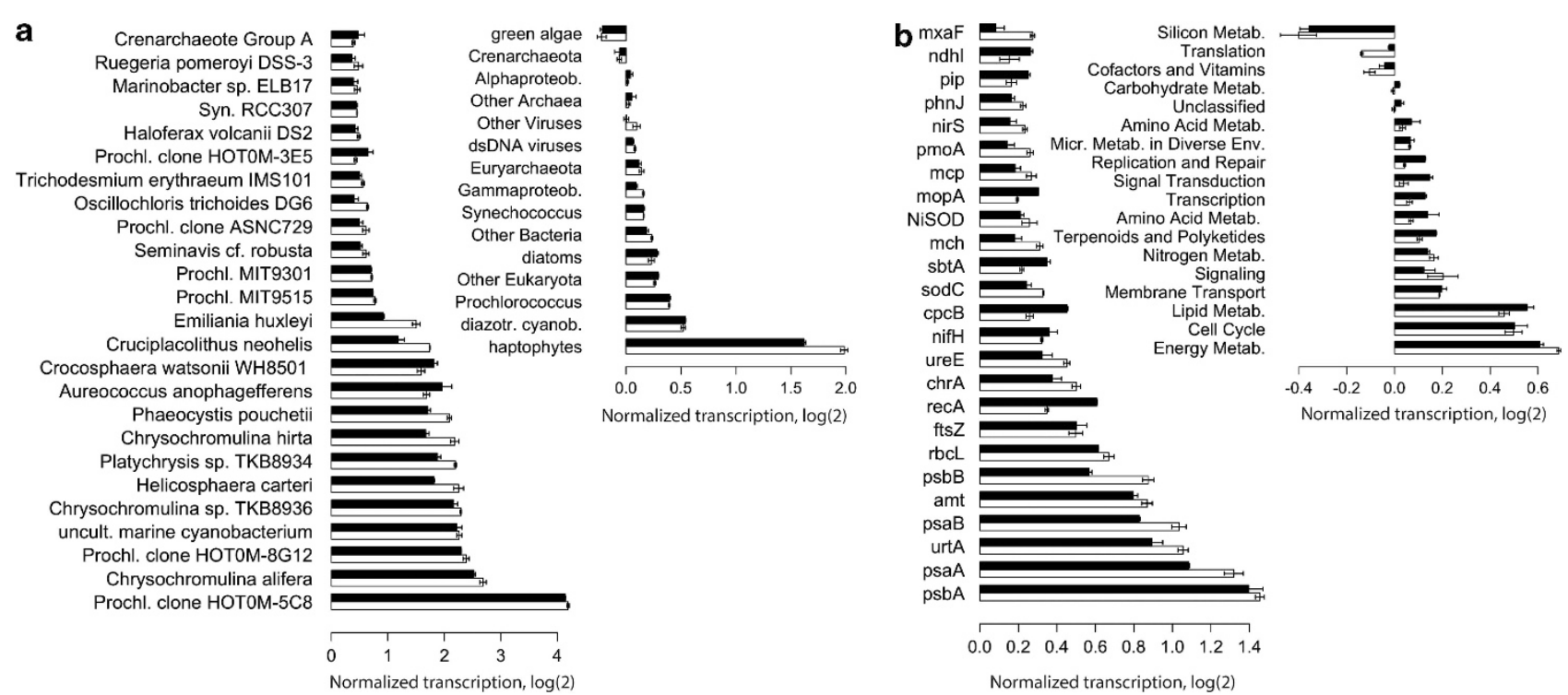

Figure 2 Average detected transcription by organisms (a) and by genes (b) normalized to the median transcription in each phylogroup in each sample. Only top 25 entries for each category are shown. Average transcription by phylogroups (a) and by gene pathways (b) are included as inserts. White and black represent P- and Fe-amended treatments, correspondingly.

Table 2 Cyanobacterial abundances measured as gene copy numbers with qPCR and chlorophyll $a$ and Fv/Fm measured with FRRF

\begin{tabular}{|c|c|c|c|c|c|c|}
\hline & \multicolumn{3}{|c|}{ Treatments } & \multicolumn{3}{|c|}{$\mathrm{t}$-value } \\
\hline & Cnt & $P$ & $\mathrm{Fe}$ & P-Cnt & $F e-C n t$ & $F e-P$ \\
\hline Synechococcus, narB L-1 & $3.2 \pm 0.9 \mathrm{E}+03$ & $6.7 \pm 1.3 \mathrm{E}+03$ & $7.4 \pm 2.0 \mathrm{E}+04$ & $0.22(n=6)$ & $4.53 * *(n=6)$ & $4.31 * *(n=6)$ \\
\hline Ca. A. thalassa, nifH L-1 & $1.3 \pm 0.2 \mathrm{E}+03$ & $3.2 \pm 0.6 \mathrm{E}+03$ & $2.4 \pm 1.0 \mathrm{E}+04$ & $0.26(n=6)$ & $3.10 *(n=6)$ & $2.84 *(n=6)$ \\
\hline Crocosphaera, nifH L-1 & $4.3 \pm 0.6 \mathrm{E}+04$ & $1.4 \pm 0.4 \mathrm{E}+05$ & $3.2 \pm 1.1 \mathrm{E}+05$ & $1.11(n=6)$ & $3.19 *(n=6)$ & $2.09(n=6)$ \\
\hline $\mathrm{Fm}$ & $3.71 \pm 0.28$ & $4.39 \pm 0.16$ & $4.18 \pm 0.44$ & $1.85(n=9)$ & $1.13(n=9)$ & $-0.61(n=9)$ \\
\hline $\mathrm{Fv} / \mathrm{Fm}$ & $0.50 \pm 0.04$ & $0.48 \pm 0.01$ & $0.43 \pm 0.01$ & $-1.07(n=9)$ & $-2.77^{*}(n=9)$ & $-1.96(n=9)$ \\
\hline
\end{tabular}

Abbreviations: Cnt, control; Fv/Fm, ratio of variable to maximum fluorescence; FRRF, Fast Repetition Rate Fluorometer; qPCR, quantitative PCR. Tukey's significance test: ${ }^{* *} 0.01,{ }^{*} 0.05$.

\section{Differential transcriptional responses to $P$ and Fe amendments}

After $48 \mathrm{~h}$ of incubation, $\mathrm{Fe}$ and $\mathrm{P}$ amendments yielded significant differences in transcript levels across the microbial community despite the high variability among biological replicates. When transcription of all genes was compared, biological replicates had a weak-positive-to-weak-negative correlation (Supplementary Table S4). Strong correlations between replicates were obtained at the level of specific phylogroups (eukaryotic, Prochlorococcus and Synechococcus) and metabolic functions (energy and $\mathrm{N}$ metabolism) (Figure 4). Factors that may have caused discrepancies in transcription profiles between replicates include differences in biological processes within individual bottles (such as protist grazing, viral lysis) and biases of sample collection and processing.

The Significance Analysis of Microarray analysis (see Materials and methods section) identified 3742 genes as significantly differentially transcribed between treatments $(\mathrm{FDR}=0.05)$ from a total of 15507 genes with detected transcription
(Supplementary Figure S5, Supplementary Table S5). Overall, the addition of $\mathrm{Fe}$ resulted in the increased transcription of 1699 genes encoding for $\mathrm{N}$ metabolism, photosynthesis, oxidative phosphorylation and ABC-type transporters (Figure 4f). The category of genes not assigned to a KEGG pathway (NA) and upregulated in the $\mathrm{Fe}$ amendment included genes for ammonium transport, organic P assimilation, DNA replication and cell division. The 2043 genes upregulated in the $\mathrm{P}$ amendment were enriched in genes for carbon fixation (Figure 4g).

It is important to note that highly transcribed genes in all samples (for example, eukaryotic nitrate reductase NR NCBI GI: GU203403 (Supplementary Table S2) oversaturated the hybridization signal, and the difference in transcription could not be estimated.

\section{Relief from Fe limitation in oligotrophic taxa}

Transcriptional patterns showed that Fe amendment resulted in relief from $\mathrm{Fe}$ limitation in taxa common to oligotrophic waters. 

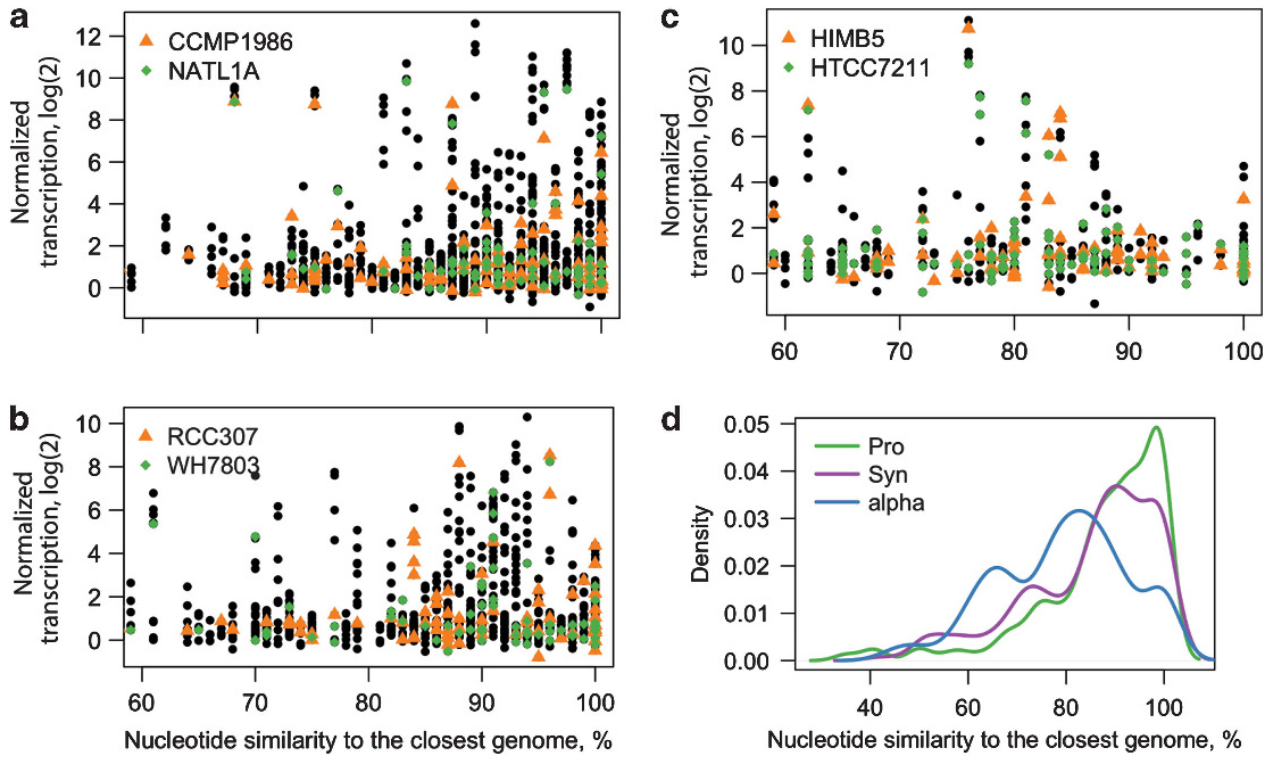

Figure 3 Transcription versus nucleotide similarity to the closest genome for Prochlorococcus spp. (a), with CCMP1986- and NATL1Alike genotypes highlighted; Synechococcus spp. (b), with RCC307- and WH7803-like genotypes highlighted; and Alphaproteobacteria (c) sequences, with HIMB5-and HTCC7211-like genotypes highlighted. Transcription was normalized to the median of each group in each sample, and only differentially transcribed genes are shown. (d) Distribution of differentially transcribed genes by nucleotide similarity to the closest genome for Prochlorococcus, Synechococcus and Alphaproteobacteria.

Transcription of genes for energy metabolism increased in picocyanobacteria upon Fe amendment (Figures 5a and b). Fe additions resulted in a twofold increased transcription of psaA (photosystem I) in both Prochlorococcus and Synechococcus spp, with an up to fivefold increase in transcript level for the psaA gene in the Synechococcus RCC307-like genotype. Transcription of the $\operatorname{cox} A$ gene (cytochrome $c$ oxidase) in Prochlorococcus eHLI and eHLII genotypes was up to fivefold higher in the Fe-amended treatment. The role of $\mathrm{Fe}$ as a cofactor in electron transport is consistent with increases in transcripts for energy-metabolism genes in Prochlorococcus and Synechococcus in $\mathrm{Fe}$ amendments, a pattern also observed in cultures (for example, Singh et al., 2003; Thompson et al., 2011).

This increased transcription of energy-metabolism genes was accompanied by the increased transcription of genes for cellular activity (DNA replication recA, cell division ftsZ) in Prochlorococcus (high light ecotype I, eHLI) in Fe-amended treatments (Supplementary Figure S6). It is possible that addition of $\mathrm{Fe}$ resulted in the increased growth rate of Prochlorococcus as observed in the Eastern South Pacific (Mann and Chisholm, 2000). The higher sensitivity of the HLI ecotype in comparison to LL ecotypes to $\mathrm{Fe}$ availability (Thompson et al., 2011) may explain the increased cellular activity of Prochlorococcus eHLI in response to the Fe amendment. The availability of fixed $\mathrm{N}$ from diazotrophs (Mulholland and Capone, 2001; Mulholland et al., 2004) upon Fe amendment may have been an additional or alternative factor that enhanced the growth of Prochlorococcus eHLI in these treatments. This hypothesis is consistent with the similarity in responses of diazotrophs and Prochlorococcus HL spp. to Fe addition, both in this study and in a study in the Southwest Pacific Ocean (Moisander et al., 2012).

The downregulation of idiA in oligotrophic taxa such as Prochlorococcus AS9601 (eHLII) and Alphaproteobacteria SAR11 clade strain HIMB59 (Supplementary Figure S6) in Fe amendments was consistent with the repression of the gene in $\mathrm{Fe}$ replete cultures (Bagg and Neilands, 1987; Webb et al., 2001; Smith et al., 2010; Thompson et al., 2011). In contrast, idiA transcription by more eutrophic Synechococcus RCC307-like (sub-cluster 5.3A, MellaFlores et al., 2011) and Pelagibacter HTCC7211-like genotypes was higher in the Fe-amendment. The differences between coastal and open ocean species have been reported before in cultures and include differences in $\mathrm{Fe}$ requirements and sensing (for example, Sunda et al., 1991; Palenik et al., 2006), uptake of siderophore- or porphyrin-bound $\mathrm{Fe}$ (Hutchins et al., 1999) and post-translational regulation by antisense RNA (Hernández et al., 2006).

This is the first report that validates differential Fe responses across a multitude of taxa in a mixed community. The relatively high $\left(0.44 \mathrm{nmoll}^{-1}\right)$ average $\mathrm{Fe}$ concentrations in the surface waters at Stn. ALOHA are not usually considered limiting for microbial communities (Boyle et al., 2005). The response to $\mathrm{Fe}$ amendments reported here indicates that either $\mathrm{Fe}$ concentrations at the time of study were lower than average or that much of this Fe was not bioavailable, at least for some taxa. 

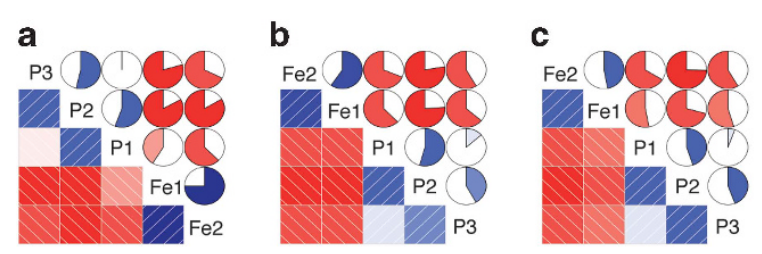

f

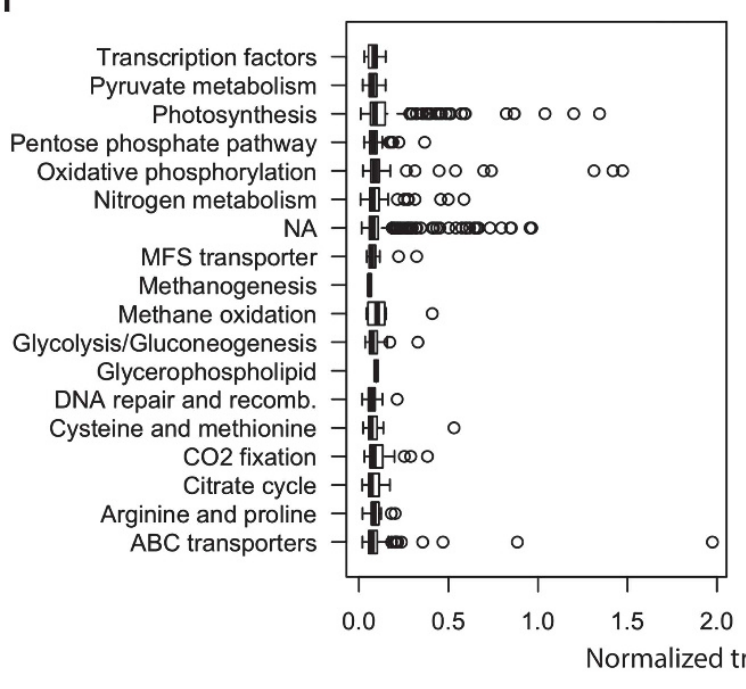

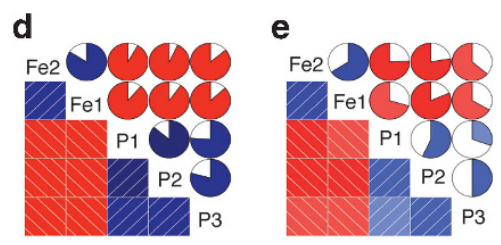

g

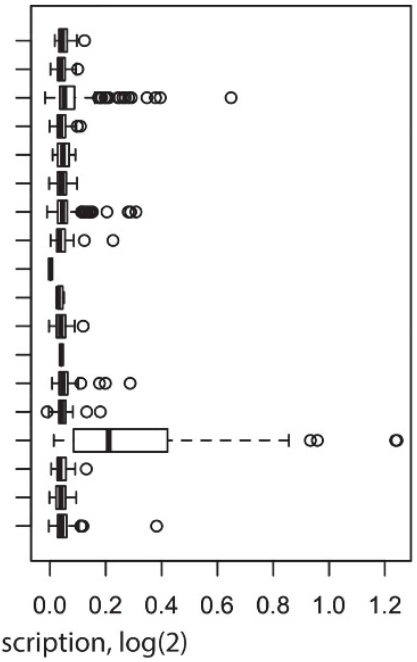

Figure 4 Correlograms for differentially transcribed genes from (a) Eukaryota (172 genes), (b) Prochlorococcus (2022 genes), (c) Synechococcus (1030 genes), (d) Energy metabolism (699 genes) and (e) Nitrogen metabolism (472 genes). The low triangle from the principal diagonal line in each panel contains correlation cells for each pair of samples, and the upper triangle contains pie charts showing the strength of correlation. Blue and red represent positive and negative correlations, respectively, and color intensity reflects magnitude of the correlation. Columns and rows were reordered based on principal component to reflect samples that group together. Correlation coefficients for all correlograms are in Supplementary Material (Supplementary Table S4). Transcription of genes upregulated in the Fe amendment (f) and in the P amendment (g) by KEGG pathway. Transcription was normalized to the mean across samples. 'NA' category comprises of genes not assigned to a KEGG pathway.

\section{Increased $N$ metabolism and $N$ limitation in $\mathrm{Fe}$ amendments}

The availability of Fe led to an increased transcription of $\mathrm{N}$ transport and metabolism genes (amt, urt $A$, $n r t P, \operatorname{gln} A, \operatorname{nir} A, \operatorname{sig} A I I)$ in both Synechococcus and Prochlorococcus and possibly led to $\mathrm{N}$ limitation in Prochlorococcus eHL (Figure 5c, Supplementary Table S6). The observed fourfold downregulation of the rbcL transcripts in Prochlorococcus eHLI and eHLII in the Fe amendment (Figure 5d) might have resulted from $\mathrm{N}$ limitation (Tolonen et al., 2006). In contrast, Synechococcus spp. had twofold higher $r b c L$ transcription in $\mathrm{Fe}$ amendments than in $\mathrm{P}$ amendments (Supplementary Table S6). We speculate that the differences in $r b c L$ transcription were due to the ability of the majority of Synechococcus spp. to assimilate nitrate, while only few uncultured Prochlorococcus spp. have that capability (Moore et al., 2002; Martiny et al., 2009). Transcription of nitrite/nitrate-utilization genes (nrtP, nirA and narB) was detected in Synechococcus spp. and was upregulated in Synechococcus WH8109 (clade II) in Fe amendments (Supplementary Tables S2 and S6). Transcription of the narB gene was also detected for a few uncultured Prochlorococcus spp., but the precise affiliation of these genes is unknown.
While not measured directly in the incubations, nitrate/nitrite concentrations at Stn. ALOHA during incubation were relatively high. It is possible that Synechococcus spp. were able to obtain sufficient nitrogen, and thus carbon fixation in Synechococcus was not downregulated.

The eukaryotic NR gene was upregulated in Fe amendments (Supplementary Table S6) possibly resulting from increased energy production, by sufficient $\mathrm{Fe}$ requirements for the nitrate reductase enzyme and/or by subsequent $\mathrm{N}$ limitation. Although transcription of $N R$ can be induced by the presence of nitrate alone in eukaryotes (Song and Ward, 2004; Poulsen and Kröger, 2005), the lower Fv/Fm ratio was possibly due to insufficient $\mathrm{N}$ (Tolonen et al., 2006) for the dominant phytoplankton in chlorophyll $a$ measurements, which at that time were eukaryotic phytoplankton. Similar to Prochlorococcus, eukaryotic phytoplankton downregulated rbcL genes in the Fe treatment, especially two Chrysophytes, Epipyxis pulchra and Ochromonas aestuarti, and two Prymnesiophytes, Chrysochromulina alifera and Chrysochromulina flava (Figure 5d). The downregulation of $r b c L$ could be due to a reduced cellular $\mathrm{N}: \mathrm{C}$ ratio in these organisms. Alternatively, if photosynthetic eukaryotic 
Syn. RS9916|psaB|89 Syn. RCC307|psaA|93 Syn. RCC307|psaA|93 Syn. RCC307|psaA|93 Syn. RCC307|psaA|94 Syn. RCC307|psaA|92
Syn. RCC307|psaA|91 Syn. RCC307|psaA|92 Syn. RCC307|psaA|90 Syn. RCC307|psaA|94 Syn. CC9311|psbA|79 Prochl. UH18301|psaA|94 Prochl. NATL1A|psbA|87 Prochl. MIT9515|psbA|91 Prochl. MIT9515|psbA|94 Prochl. MIT9312|psaA|74 Prochl. MIT9301|psbA|78 Prochl. MIT9202|psaA|99 Prochl. MIT9202/psbB|95 Prochl. CCMP1986|psaA|90 Prochl. AS9601|psaA|96

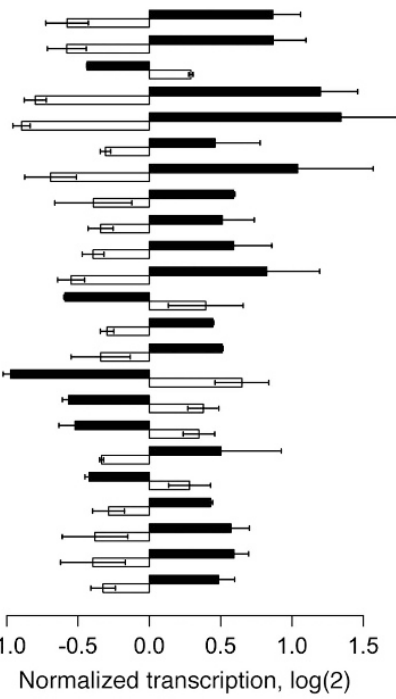

C Prochl. clone HOTOM-8G12 |amt|92 Prochl. clone HOTOM-8G12|amt|88 Prochl. clone HOTOM-8G12|amt|90 Syn. JA-3-3Ab|glnA|73 Syn. JA-3-3Ab|ginA 64 Syn. JA-2-3B'a 2-13 $|\operatorname{gn} A| 58$ Syn. CC9311|urtA|96 Prochl. NATL2A|glnA|99 Prochl. MIT9312|amt|100 Prochl. MIT9312|urtA|88 Prochl. MIT9215|amt|85 Prochl. MIT9215|amt|62 Prochl. MIT9215|carAl41 Prochl. MIT 215 Prochl. MIT9215|amt|94 Prochl. MIT9215|amt|77 Prochl. MIT9202/glnA|100 Prochl. CCMP1986|gInA|100 Prochl. CCMP1986|amt|100 Prochl. CCMP1986|ureD|92 Prochl. AS9601|amt|94 Prochl. AS9601|amt|87 Prochl. AS9601|urtA|94

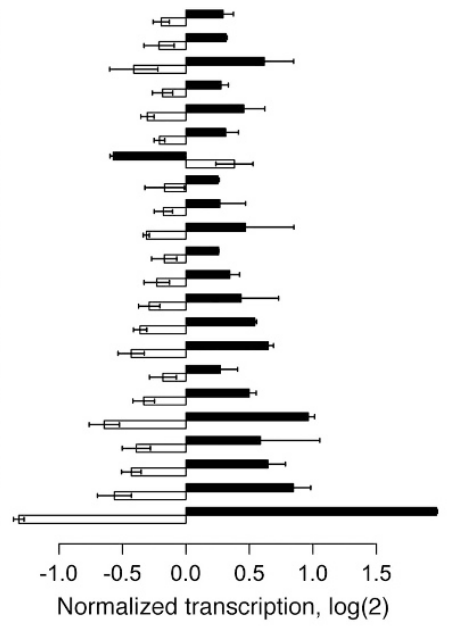

d

b

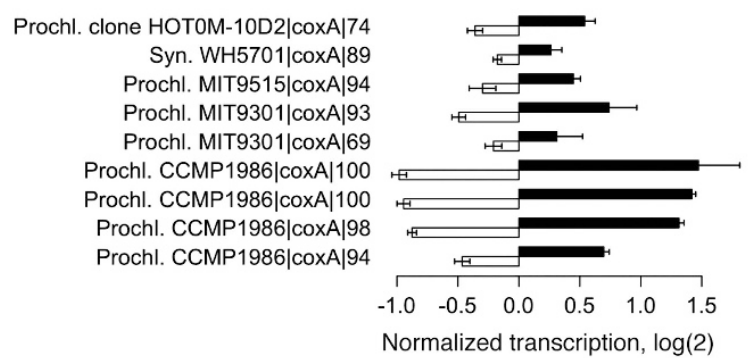

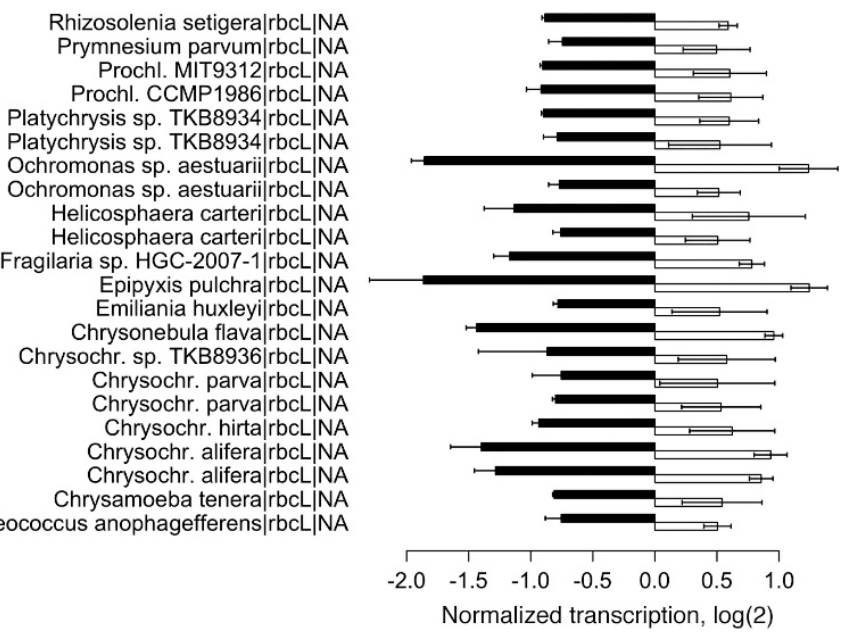

Figure 5 Normalized transcription for top differentially transcribed genes for (a) photosynthesis, (b) oxidative phosphorylation, (c) nitrogen metabolism and stress and (d) carbon fixation. Transcription was normalized to the mean transcription across samples.

phytoplankton were utilizing nitrate, they would have had to divert ATP and reductant away from carbon fixation, which would also result in decreased carbon fixation (Laws, 1991) by downregulating rbcL transcription.

\section{$P$ limitation or increased P metabolism followed Fe addition}

Individual taxa in the Fe treatment showed upregulated transcription of $\mathrm{P}$ stress-response genes, despite the generally high availability of phosphate. Transcription of pstS (the high-affinity phosphate-binding protein) in Prochlorococcus MIT9301-like genotypes (eHLII) was twofold higher in the $\mathrm{Fe}$ amendments in comparison to the $\mathrm{P}$ amendments (Supplementary Figure S6). The set of iron upregulated genes was enriched in pstS transcripts from Proteobacteria (especially, Alphaproteobacterium HIMB5) and cyanobacteria (Synechococcus WH8102) (Supplementary Table S6). The phosphonate utilization genes phnJ and phnA in Alphaproteobacteria and the alkaline phosphatase gene phoD in Gammaproteobacteria were upregulated in the Fe addition (Supplementary Figure S6, Supplementary Table S6). The 2- $\mu \mathrm{m}$ size fraction of phytoplankton was not P-depleted at the time of incubation (Björkman et al., 2012), but it is possible that $\mathrm{P}$ limitation was induced by the fast removal of $\mathrm{P}$ in the $\mathrm{Fe}$ amendment by some members of the community, such as nitrate utilizers. Alternatively, increased energy generation in microorganisms in the Fe treatment might have provided energy for phosphate acquisition and membrane translocation systems for proteins involved in alternative $\mathrm{P}$ source assimilation (Cembella et al., 1982; Jansson, 1988; Tetu et al., 2009). Taxa that upregulated $\mathrm{P}$ transport and metabolism genes were largely different from taxa that demonstrated $\mathrm{N}$ limitation, but manifestations of both $\mathrm{N}$ and $\mathrm{P}$ limitations occurred after Fe was supplied, suggesting Fe as a primary limiting nutrient at that time. 


\section{Conclusions}

This study reports the design of a high-density oligonucleotide microarray (MicroTOOLs) that targets marine microbial communities and was enabled by currently available environmental sequence data. We detected differential microbial community responses to nutrient amendments in the NPSG, ultimately demonstrating strain-specific community responses to relief of Fe stress that was followed by $\mathrm{N}$ or $\mathrm{P}$ limitation in some taxa. Such data provide a mechanistic understanding of changes in microbial communities in response to nutrient fluxes or other environmental factors.

Future technological improvements, such as automated probe design including probes for other marker genes and exploratory probes (Chung et al., 2005; Dugat-Bony et al., 2011), would improve the performance of the microarray. In addition to the utility of the MicroTOOLs array for incubation experiments, this microarray could be applied as a tool for pelagic marine microbiological studies for standardized information across study types and ocean basins. This would result in a high-resolution map of microbial genes and their transcriptional activities in the environment and provide the baseline for assessing the impacts of future perturbations of the global ocean.

\section{Conflict of Interest}

The authors declare no conflict of interest.

\section{Acknowledgements}

This work resulted from two workshops, and the design of the microarray was partially supported by the Gordon and Betty Moore Foundation (the MEGAMER facility), by a Gordon and Betty Moore Foundation Marine Investigator grant (JPZ) and by the NSF Center for Microbial Oceanography (C-MORE, NSF EF0424599). We thank all the participants of the October 2010 MicroTOOLs workshop sponsored by the Moore foundation. Particularly, we thank those who provided sequences for the design of microarray: Mahdi Belcaid, Dreux Chappell, Jackie Collier, Chris Francis, Scott Gifford, Jana Grote, Bethany Jenkins, Julie LaRoche, Pia Moisander, Annika Mosier, Micaela Parker, Holly Simon, Mariya Smit, Jody Wright, and Louie Wurch. We thank Shulei Sun and the team at CAMERA for support during microarray design. We also thank the Hawaii Ocean Time-series (HOT) program and C-MORE, specifically the captain and crew of R/V Kilo Moana and chief scientist of KM1016 cruise, Matt Church, for their expertise and for providing the opportunity and support for conducting experiments at sea. We thank Philip Heller and Jonathan Magasin for developing Java scripts for the microarray design and for computational support during the MicroTOOLs workshop in October 2010. Finally, we thank Nicole Pereira for help in running the incubation experiment, Sasha Tozzi for FRRF measurements, Rob Tibshirani for a consultation on microarray data normalization and analysis and the JPZ laboratory members for constructive discussions.

\section{References}

Abell GCJ, Robert SS, Frampton DMF, Volkman JK, Rizwi F et al. (2012). High-throughput analysis of ammonia oxidiser community composition via a novel, amoAbased functional gene array. PLoS One 7: e51542.

Ahlgren NA, Rocap G. (2012). Diversity and distribution of marine Synechococcus: multiple gene phylogenies for consensus classification and development of qPCR assays for sensitive measurement of clades in the ocean. Front Microbio 3: 213.

Allen LZ, Allen EE, Badger JH, McCrow JP, Paulsen IT, Elbourne LDH et al. (2012). Influence of nutrients and currents on the genomic composition of microbes across an upwelling mosaic. ISME J 6: 1403-1414.

Armbrust EV, Berges JA, Bowler C, Green BR, Martinez D, Putnam NH et al. (2004). The genome of the diatom Thalassiosira pseudonana: ecology, evolution, and metabolism. Science 306: 79-86.

Azam F, Malfatti F. (2007). Microbial structuring of marine ecosystems. Nat Rev Microbiol 5: 782-791.

Bagg A, Neilands JB. (1987). Ferric uptake regulation protein acts as a repressor, employing iron (II) as a cofactor to bind the operator of an iron transport operon in Escherichia coli. Biochemistry 26: 5471-5477.

Bai S, Li J, He Z, Van Nostrand JD, Tian Y, Lin G et al. (2013). GeoChip-based analysis of the functional gene diversity and metabolic potential of soil microbial communities of mangroves. Appl Microbiol Biotechnol 97: 7035-7048.

Bauer DF. (1972). Constructing confidence sets using rank statistics. J Am Stat Assoc 67: 687-690.

Benjamini Y, Hochberg Y. (1995). Controlling the false discovery rate: a practical and powerful approach to multiple testing. J R Stat Soc Ser B (Methodological) 57: 289-300.

Björkman K, Duhamel S, Karl DM. (2012). Microbial group specific uptake kinetics of inorganic phosphate and adenosine-5'-triphosphate (ATP) in the North Pacific Subtropical Gyre. Front Microbiol 3: 189; doi:10.3389/ fmicb.2012.00189.

Bouskill NJ, Eveillard D, O’Mullan G, Jackson GA, Ward BB. (2011). Seasonal and annual reoccurrence in betaproteobacterial ammonia-oxidizing bacterial population structure. Environ Microbiol 13: 872-886.

Bowler C, Allen AE, Badger JH, Grimwood J, Jabbari K, Kuo A et al. (2008). The Phaeodactylum genome reveals the evolutionary history of diatom genomes. Nature 456: 239-244.

Boyle EA, Bergquist BA, Kayser RA, Mahowald N. (2005). Iron, manganese, and lead at Hawaii Ocean Timeseries station ALOHA: temporal variability and an intermediate water hydrothermal plume. Geochim Cosmochim Acta 69: 933-952.

Brazma A, Hingamp P, Quackenbush J, Sherlock G, Spellman P, Stoeckert C et al. (2001). Minimum information about a microarray experiment (MIAME)—-toward standards for microarray data. Nat Genet 29: 365-371.

Brodie EL, DeSantis TZ, Joyner DC, Baek SM, Larsen JT, Andersen GL et al. (2006). Application of a high-density oligonucleotide microarray approach to study bacterial population dynamics during uranium reduction and reoxidation. Appl Environ Microbiol 72: 6288-6298.

Brown MV, Lauro FM, DeMaere MZ, Muir L, Wilkins D, Thomas T et al. (2012). Global biogeography of SAR11 marine bacteria. Mol Syst Biol 8: 595. 
Bulow SE, Francis CA, Jackson GA, Ward BB. (2008). Sediment denitrifier community composition and nirS gene expression investigated with functional gene microarrays. Environ Microbiol 10: 3057-3069.

Cembella AD, Antia NJ, Harrison PJ. (1982). The utilization of inorganic and organic phosphorous compounds as nutrients by eukaryotic microalgae: a multidisciplinary perspective: Part I. Crit Rev Microbiol 10: 317-391.

Chen F, Wang K, Kan JJ, Bachoon DS, Lu JR, Lau S et al. (2004). Phylogenetic diversity of Synechococcus in the Chesapeake Bay revealed by ribulose-1,5-bisphosphate carboxylase-oxygenase (RuBisCO) large subunit gene (rbcL) sequences. Aquat Microb Ecol 36: 153-164.

Chung WH, Rhee SK, Wan XF, Bae JW, Quan ZX, Park YH. (2005). Design of long oligonucleotide probes for functional gene detection in a microbial community. Bioinformatics 21: 4092-4100.

Church MJ, Mahaffey C, Letelier RM, Lukas R, Zehr JP, Karl DM. (2009). Physical forcing of nitrogen fixation and diazotroph community structure in the North Pacific Subtropical Gyre. Glob Biogeochem Cycles 23: GB2020.

Church MJ, Short CM, Jenkins BD, Karl DM, Zehr JP. (2005). Temporal patterns of nitrogenase gene (nifH) expression in the oligotrophic North Pacific Ocean. Appl Environ Microbiol 71: 5362-5370.

Coleman ML, Chisholm SW. (2010). Ecosystem-specific selection pressures revealed through comparative population genomics. Proc Natl Acad Sci USA 107: 18634-18639.

DeLong EF, Preston CM, Mincer T, Rich V, Hallam SJ, Frigaard NU et al. (2006). Community genomics among stratified microbial assemblages in the ocean's interior. Science 311: 496-503.

Dugat-Bony E, Peyretaillade E, Parisot N, Biderre-Petit C, Jaziri F, Hill D et al. (2011). Detecting unknown sequences with DNA microarrays: explorative probe design strategies. Environ Microbiol 14: 356-371.

Dupont CL, Barbeau K, Palenik B. (2008). Ni uptake and limitation in marine Synechococcus strains. Appl Environ Micro 74: 23-31.

Dyhrman ST, Haley ST. (2006). Phosphorus scavenging in the unicellular marine diazotroph Crocosphaera watsonii. Appl Environ Microbiol 72: 1452-1458.

Frias-Lopez J, Shi Y, Tyson GW, Coleman ML, Schuster SC, Chisholm SW et al. (2008). Microbial community gene expression in ocean surface waters. Proc Natl Acad Sci USA 105: 3805-3810.

Fuhrman JA, Hewson I, Schwalbach MS, Steele JA, Brown MV, Naeem S. (2006). Annually reoccurring bacterial communities are predictable from ocean conditions. Proc Natl Acad Sci USA 103: 13104-13109.

Fuller NJ, West NJ, Marie D, Yallop M, Rivlin T, Post AF et al. (2005). Dynamics of community structure and phosphate status of picocyanobacterial populations in the Gulf of Aqaba, Red Sea. Limnol Oceanogr 50: 363-375.

Gautier L, Cope L, Bolstad BM, Irizarry RA. (2004). affy analysis of Affymetrix GeneChip data at the probe level. Bioinformatics 20: 307-315.

Gentleman RC, Carey VJ, Bates DM, Bolstad B, Dettling M, Dudoit $S$ et al. (2004). Bioconductor: open software development for computational biology and bioinformatics. Genome Biol 5: R80.

Giovannoni SJ, Vergin KL. (2012). Seasonality in ocean microbial communities. Science 335: 671-676.
Grabowski M, Church M, Karl D. (2008). Nitrogen fixation rates and controls at Stn. ALOHA. Aquat Microb Ecol 52: 175-183.

He Z, Deng Y, Van Nostrand JD, Tu Q, Xu M, Hemme CL et al. (2010). GeoChip 3.0 as a high-throughput tool for analyzing microbial community composition, structure and functional activity. ISME J 4: 1167-1179.

He Z, Gentry TJ, Schadt CW, Wu L, Liebich J, Chong SC et al. (2007). GeoChip: a comprehensive microarray for investigating biogeochemical, ecological and environmental processes. ISME J 1: 67-77.

Hernández JA, Muro-Pastor AM, Flores E, Bes MT, Peleato ML, Fillat MF. (2006). Identification of a furA cis antisense RNA in the cyanobacterium Anabaena sp. PCC 7120. J Mol Biol 355: 325-334.

Hewson I, Poretsky RS, Tripp HJ, Montoya JP, Zehr JP. (2010). Spatial patterns and light-driven variation of microbial population gene expression in surface waters of the oligotrophic open ocean. Environ Microbiol 12: 1940-1956.

Holtzendorff J, Marie D, Post AF, Partensky F, Rivlin A, Hess WR. (2002). Synchronized expression of fts $Z$ in natural Prochlorococcus populations of the Red Sea. Environ. Microbiol 4: 644-653.

Huang S, Wilhelm SW, Harvey HR, Taylor K, Jiao N, Chen F. (2012). Novel lineages of Prochlorococcus and Synechococcus in the global oceans. ISME J 6: 285-297.

Huang Y, Niu B, Gao Y, Fu L, Li W. (2010). CD-HIT suite: a web server for clustering and comparing biological sequences. Bioinformatics 26: 680-682.

Hutchins DA, Witter AE, Butler A, Luther GW. (1999). Competition among marine phytoplankton for different chelated iron species. Nature 400: 858-861.

Ilikchyan IN, McKay RM, Zehr JP, Dyhrman ST, Bullerjahn GS. (2009). Detection and expression of the phosphonate transporter gene $p h n D$ in marine and freshwater picocyanobacteria. Environ Microbiol 11: 1314-1324.

Irizarry RA, Hobbs B, Collin F, Beazer-Barclay YD, Antonellis KJ, Scherf U et al. (2003). Exploration, normalization, and summaries of high density oligonucleotide array probe level data. Biostatistics 4: 249-264.

Jansson M. (1988). Phosphate uptake and utilization by bacteria and algae. Hydrobiologia 170: 177-189.

Kamennaya NA, Post AF. (2011). Characterization of cyanate metabolism in marine Synechococcus and Prochlorococcus spp. Appl Environ Microbiol 77: 291-301.

Karl DM, Björkman KM, Dore JE, Fujieki L, Hebel DV, Houlihan $\mathrm{T}$ et al. (2001). Ecological nitrogento-phosphorus stoichiometry at Station ALOHA. Deep-Sea Res II 48: 1529-1566.

Karl DM, Letelier R. (2008). Nitrogen fixation-enhanced carbon sequestration in low nitrate, low chlorophyll seascapes. Mar Ecol Prog Ser 364: 257-268.

Karl DM, Letelier R, Tupas L, Dore J, Christian J, Hebel D. (1997). The role of nitrogen fixation in biogeochemical cycling in the subtropical North Pacific Ocean. Nature 388: $533-538$.

Karl DM, Lukas R. (1996). The Hawaii ocean time-series (HOT) program: background, rationale, and field implementation. Deep-Sea Res II 43: 129-156.

Kolber ZS, Prasil O, Falkowski PG. (1998). Measurements of variable chlorophyll fluorescence using fast repetition rate techniques: defining methodology and experimental protocols. Biochim Biophys Acta Bioenerg 1367: 88-106. 
Laws EA. (1991). Photosynthetic quotients, new production and net community production in the open ocean. Deep-Sea Res Oceanogr A 38: 143-167.

Lemire A, Lea K, Batten D, Gu J, Whitley P, Bramlett K. (2011). Development of ERCC RNA spike-in control mixes. J Biomol Tech 22: S46.

Li C, Wong WH. (2001). Model-based analysis of oligonucleotide arrays: expression index computation and outlier detection. Proc Natl Acad Sci USA 98: 31-36.

Li W, Godzik A. (2006). CD-HIT: a fast program for clustering and comparing large sets of protein or nucleotide sequences. Bioinformatics 22: 1658-1659.

Lindell D, Post AF. (2001). Ecological aspects of $n t c A$ gene expression and its use as an indicator of the nitrogen status of marine Synechococcus spp. Appl Environ Microbiol 67: 3340-3349.

Lu Z, Deng Y, Van Nostrand JD, He Z, Voordeckers J, Zhou A et al. (2012). Microbial gene functions enriched in the Deepwater Horizon deep-sea oil plume. ISME J 6: 451-460.

Mann EL, Chisholm SW. (2000). Iron limits the cell division rate of Prochlorococcus in the eastern equatorial Pacific. Limnol Oceanogr 45: 1067-1076.

Martiny AC, Kathuria S, Berube PM. (2009). Widespread metabolic potential for nitrite and nitrate assimilation among Prochlorococcus ecotypes. Proc Natl Acad Sci USA 106: 10787-10792.

Mason OU, Nakagawa T, Rosner M, Van Nostrand JD, Zhou J. (2010). First investigation of the microbiology of the deepest layer of ocean crust. PLoS One 5: e15399.

Mayer JA, Taylor FJR. (1979). Virus which lyses the marine nanoflagellate Micromonas pusilla. Nature 281: 299-301.

Mella-Flores D, Mazard S, Humily F, Partensky F, Mahé F, Bariat L et al. (2011). Is the distribution of Prochlorococcus and Synechococcus ecotypes in the Mediterranean Sea affected by global warming. Biogeosciences 8: $2785-2804$.

Milligan KLD, Cosper EM. (1994). Isolation of virus capable of lysing the brown tide microalga, Aureococcus anophagefferens. Science 266: 805-807.

Moisander PH, Beinart RA, Hewson I, White AE, Johnson KS, Carlson CA et al. (2010). Unicellular cyanobacterial distributions broaden the oceanic $\mathrm{N}_{2}$ fixation domain. Science 327: 1512-1514.

Moisander PH, Morrison AE, Ward BB, Jenkins BD, Zehr JP. (2007). Spatial-temporal variability in diazotroph assemblages in Chesapeake Bay using an oligonucleotide nifH microarray. Environ Microbiol 9: 1823-1835.

Moisander PH, Shiue L, Steward GF, Jenkins BD, Bebout BM, Zehr JP. (2006). Application of a nifH oligonucleotide microarray for profiling diversity of $\mathrm{N}_{2}$-fixing microorganisms in marine microbial mats. Environ Microbiol 8: $1721-1735$.

Moisander PH, Zhang R, Boyle EA, Hewson I, Montoya JP, Zehr JP. (2012). Analogous nutrient limitations in unicellular diazotrophs and Prochlorococcus in the South Pacific Ocean. ISME J 6: 733-744.

Moore JK, Donney SC, Lindsay K, Mahowald N, Michaels AF. (2006). Nitrogen fixation amplifies the ocean biogeochemical response to decadal timescale variations in mineral dust deposition. Tellus Ser B 58: 560-572.

Moore LR, Post AF, Rocap G, Chisholm SW. (2002). Utilization of different nitrogen sources by the marine cyanobacteria, Prochlorococcus and Synechococcus. Limnol Oceanogr 47: 989-996.
Mosier AC, Francis CA. (2011). Determining the distribution of marine and coastal ammonia-oxidizing archaea and bacteria using a quantitative approach. In: Klotz MG (ed) Methods in Enzymology: Research on Nitrification and Related Processes, Part A, vol. 486. Elsevier Academic Press: San Diego, CA, USA, pp 205-221.

Mulholland MR, Bronk D, Capone DG. (2004). Dinitrogen fixation and release of ammonium and dissolved organic nitrogen by Trichodesmium IMS101. Aquat Microb Ecol 37: 85-94.

Mulholland MR, Capone DG. (2001). Stoichiometry of nitrogen and carbon utilization in cultured populations of Trichodesmium IMS101: Implications for growth. Limnol Oceanogr 46: 436-443.

Neidhardt FC, Umbarger HE. (1996). Chemical composition of Escherichia coli. In: Neidhardt FC, Curtiss III R, Ingraham JL, Lin ECC, Low KB, Magasanik B, Reznikoff WS et al. (eds). Escherichia coli and Salmonella: Cellular and Molecular Biology, 2nd edn. ASM Press: Washington, DC, USA, pp 13-16.

Orchard ED, Webb EA, Dyhrman S. (2009). Molecular analysis of the phosphorus starvation response in Trichodesmium spp. Environ Microbiol 11: 2400-2411.

Paerl RW, Johnson KS, Welsh RM, Worden AZ, Chavez FP, Zehr JP. (2011). Differential distributions of Synechococcus subgroups across the California Current System. Front Microbiol 2: 59.

Paerl RW, Turk KA, Beinart RA, Chavez FP, Zehr JP. (2012). Seasonal change in the abundance of Synechococcus and multiple distinct phylotypes in Monterey Bay determined by $r b c L$ and narB quantitative PCR. Environ Microbiol 14: 580-593.

Palenik B, Ren QH, Dupont CL, Myers GS, Heidelberg JF, Badger JH et al. (2006). Genome sequence of Synechococcus CC9311: Insights into adaptation to a coastal environment. Proc Natl Acad Sci USA 103: 13555-13559.

Post AF, Penno S, Zandbank K, Paytan A, Huse S, Mark Welch D. (2011). Long term seasonal dynamics of Synechococcus population structure in the Gulf of Aqaba, Northern Red Sea. Front Microbiol 2: 131.

Poulsen N, Kröger N. (2005). A new molecular tool for transgenic diatoms. FEBS J 272: 3413-3423.

Rhee SK, Liu XD, Wu LY, Chong SC, Wan XF, Zhou JZ. (2004). Detection of genes involved in biodegradation and biotransformation in microbial communities by using 50-mer oligonucleotide microarrays. Appl Environ Microbiol 70: 4303-4317.

Rich VI, Konstantinidis K, DeLong EF. (2008). Design and testing of 'genome-proxy' microarrays to profile marine microbial communities. Environ Microbiol 10: $506-521$.

Rich VI, Pham VD, Eppley J, Shi Y, DeLong EF. (2011). Time-series analyses of Monterey Bay coastal microbial picoplankton using a 'genome proxy' microarray. Environ. Microbiol 13: 116-134.

Rinta-Kanto JM, Buergmann H, Gifford SM, Sun S, Sharma S, del Valle DA et al. (2011). Analysis of sulfur-related transcription by Roseobacter communities using a taxonspecific functional gene microarray. Environ Microbiol 13: $453-467$.

Scanlan DJ, Bourne JA, Mann NH. (1996). A putative transcriptional activator of the Crp/Fnr family from the marine cyanobacterium Synechococcus sp. WH7803. J Appl Phycol 8: 565-567.

Scanlan DJ, Ostrowski M, Mazard S, Dufresne A, Garczarek L, Hess WR et al. (2009). Ecological 
genomics of marine picocyanobacteria. Microbiol Mol Bio Rev 73: 249-299.

Scanlan DJ, West NJ. (2002). Molecular ecology of the marine cyanobacterial genera. FEMS Microbiol Ecol 40: 1-12.

Sebastian M, Ammerman JW. (2009). The alkaline phosphatase PhoX is more widely distributed in marine bacteria than the classical PhoA. ISME J 3: 563-572.

Shi YM, Tyson GW, DeLong EF. (2009). Metatranscriptomics reveals unique microbial small RNAs in the ocean's water column. Nature 459: 266-269.

Singh AK, McIntyre LM, Sherman LA. (2003). Microarray analysis of the genome-wide response to iron deficiency and iron reconstitution in the cyanobacterium Synechocystis sp. PCC 6803. Plant Physiol 132: 1825-1839.

Smith MW, Herfort L, Tyrol K, Suciu D, Campbell V, Crump BC et al. (2010). Seasonal changes in bacterial and archaeal gene expression patterns across salinity gradients in the Columbia River coastal margin. PLoS One 5: e13312.

Smyth GK. (2005). LIMMA: Linear Models for Microarray data. In: Gentleman R, Carey V, Dudoit S, Irizarry R, Huber W (eds) Bioinformatics and Computational Biology Solutions using $R$ and Bioconductor. Springer: New York, NY, USA, pp 397-420.

Song BK, Ward BB. (2004). Molecular characterization of the assimilatory nitrate reductase gene and its expression in the marine green alga Dunaliella tertiolecta (Chlorophyceae). J Phycol 40: 721-731.

Stuart RK, Dupont CL, Johnson DA, Paulsen IT, Palenik B. (2009). Coastal strains of marine Synechococcus exhibit increased tolerance to copper shock and a distinctive transcriptional response relative to open ocean strains. Appl Environ Microbiol 75: 5047-5057.

Sun S, Chen J, Li W, Altinatas I, Lin A, Peltier S et al. (2011). Community cyberinfrastructure for Advanced Microbial Ecology Research and Analysis: the CAMERA resource. Nucl Acids Res 39: D546-D551.

Sun J, Steindler L, Thrash JC, Halsey KH, Smith DP, Carter AE et al. (2011). One carbon metabolism in SAR11 pelagic marine bacteria. PLoS One 6: e23973.

Sunda WG, Swift DG, Huntsman SA. (1991). Low iron requirement for growth in oceanic phytoplankton. Nature 351: 55-57.

Sylvan J, Quigg A, Tozzi S, Ammerman J. (2007). Eutrophication-induced phosphorus limitation in the Mississippi River plume: evidence from fast repetition rate fluorometry. Limnol Oceanogr 52: 2679-2685.

Sylvan JB, Quigg A, Tozzi S, Ammerman JW. (2011). Mapping phytoplankton community physiology on a river impacted continental shelf: testing a multifaceted approach. Estuaries Coasts 34: 1220-1233.

Taroncher-Oldenburg G, Griner EM, Francis CA, Ward BB. (2003). Oligonucleotide microarray for the study of functional gene diversity in the nitrogen cycle in the environment. Appl Environ Microbiol 69: 1159-1171.

Tetu SG, Brahamsha B, Johnson DA, Tai V, Phillippy K, Palenik B et al. (2009). Microarray analysis of phosphate regulation in the marine cyanobacterium Synechococcus sp. WH8102. ISME J 3: 835-849.

Thompson AW, Huang K, Saito MA, Chisholm SW. (2011). Transcriptome response of high- and low-lightadapted Prochlorococcus strains to changing iron availability. ISME J 5: 1580-1594.
Tiquia SM, Wu L, Chong SC, Passovets S, Xu D, Xu Y et al. (2004). Evaluation of 50-mer oligonucleotide arrays for detecting microbial populations in environmental samples. Biotechniques 36: 664-675.

Tolonen AC, Aach J, Lindell D, Johnson ZI, Rector T, Steen R et al. (2006). Global gene expression of Prochlorococcus ecotypes in response to changes in nitrogen availability. Mol Syst Biol 2: 53.

Tusher VG, Tibshirani R, Chu G. (2001). Significance analysis of microarrays applied to the ionizing radiation response. Proc Natl Acad Sci USA 98: 5116-5121.

Vogel J, Axmann IM, Herzel H, Hess WR. (2003). Experimental and computational analysis of transcriptional start sites in the cyanobacterium Prochlorococcus MED4. Nucleic Acids Res 31: 2890-2899.

Ward BB, Eveillard D, Kirshtein JD, Nelson JD, Voytek MA, Jackson GA. (2007). Ammonia-oxidizing bacterial community composition in estuarine and oceanic environments assessed using a functional gene microarray. Environ Microbiol 9: 2522-2538.

Watkins-Brandt KS, Letelier RM, Spitz YH, Church MJ, Böttjer D, White AE. (2011). Addition of inorganic or organic phosphorus enhances nitrogen and carbon fixation in the oligotrophic North Pacific. Mar Ecol Prog Ser 432: 17-29.

Wawrik B, Boling WB, Van Nostrand JD, Xie J, Zhou J, Bronk DA. (2012). Assimilatory nitrate utilization by bacteria on the West Florida Shelf as determined by stable isotope probing and functional microarray analysis. FEMS Microbiol Ecol 79: 400-411.

Webb EA, Moffett JW, Waterbury JB. (2001). Iron stress in open-ocean cyanobacteria (Synechococcus, Trichodesmium, and Crocosphaera spp.): identification of the IdiA protein. Appl Environ Microbiol 67: 5444-5452.

White AE, Spitz YH, Letelier RM. (2007). What factors are driving summer phyto-plankton blooms in the North Pacific Subtropical Gyre? J Geophys Res 112: C12006.

Wu L, Kellogg L, Devol AH, Tiedje JM, Zhou J. (2008). Microarray-based characterization of microbial community functional structure and heterogeneity in marine sediments from the Gulf of Mexico. Appl Environ Microbiol 74: 4516-4529.

Wu LY, Thompson DK, Li GS, Hurt RA, Tiedje JM, Zhou JZ. (2001). Development and evaluation of functional gene arrays for detection of selected genes in the environment. Appl Environ Microbiol 67: 5780-5790.

Xie J, He Z, Liu X, Liu X, Van Nostrand JD, Deng Y et al. (2011). GeoChip-based analysis of the functional gene diversity and metabolic potential of microbial communities in acid mine drainage. Appl Environ Microbiol 2011: 3 .

Yergeau E, Kang S, He Z, Zhou J, Kowalchuk GA. (2007). Functional microarray analysis of nitrogen and carbon cycling genes across an Antarctic latitudinal transect. ISME J 1: 163-179.

Zehr JP, Montoya JP, Jenkins BD, Hewson I, Mondragon E, Short CM et al. (2007). Experiments linking nitrogenase gene expression to nitrogen fixation in the North Pacific subtropical gyre. Limnol Oceanogr 52: $169-183$

Zhou A, He Z, Qin Y, Lu Z, Deng Y, Tu Q et al. (2013). StressChip as a high-throughput tool for assessing microbial community responses to environmental stresses. Environ Sci Technol 47: 9841-9849. 